\title{
20. SOUTHWEST PACIFIC REGIONAL UNCONFORMITIES ENCOUNTERED DURING LEG 21
}

\author{
Anthony R. Edwards, New Zealand Geological Survey, Lower Hutt, New Zealand
}

\section{INTRODUCTION}

One of the most unexpected results of Deep Sea Drilling Project Leg 21 was the discovery of an Eocene-Oligocene regional unconformity, which is exceptionally widespread in the southwest Pacific marginal seas, and of a companion Paleocene-Eocene regional unconformity, which was proved to occur over a smaller, but still very substantial, area. In addition, at two sites, the DV Glomar Challenger for the first time recovered near complete sequences across the Mesozoic-Cenozoic boundary.

This report is intended to document these important features by providing brief descriptions of their occurrence, age, and possible on-shore correlatives. The methods by which the features were formed are not, with the exception of the Mesozoic-Cenozoic boundary, speculated upon in this paper. This omission is for a number of good reasons, including the distinct possibility that the results obtained by the forthcoming sub-Antarctic Leg 29-in which the writer will be participating-could materially add to our knowledge of these features. However, the writer generally accepts the thesis (Kennett et al., 1972) that the EoceneOligocene and (writer's inference) Paleocene-Eocene unconformities result from changes induced by southwest Pacific sea floor spreading events. These changes were almost certainly accompanied by widespread climatic change (compare with Hornibrook, 1971), but the hypothesis (Kennett et al., 1972) that the Eocene-Oligocene unconformity resulted, in part or whole, from contemporaneous Antarctic glaciation (as distinct from refrigeration) is discounted.

Already, a large amount of information relevant to these features is available in the shipboard reports of Leg 21 and is utilized here without specific reference to its origin. Accordingly, the writer acknowledges a substantial debt to his shipboard colleagues. Special acknowledgment is also due to the writer's New Zealand Geological Survey colleagues, especially to N. deB. Hornibrook for his constructive criticism of this paper and to W. A. Watters for his petrographic comments on some of the MesozoicCenozoic boundary samples.

\section{THE EOCENE-OLIGOCENE UNCONFORMITY}

\section{Occurrence}

This very widespread feature was easily recognized in Leg 21 Sites 206 to 210 inclusive in the Coral Sea and Tasman Sea areas (Burns et al., 1972; Kennett et al., 1972) which were spudded in at midbathyal to abyssal (1400 to $4600 \mathrm{~m}$ ) depths and separated by up to $23^{\circ}$ of latitude and $13^{\circ}$ of longitude (Figure 1). Descriptions of the situations observed at each location follow.

\section{Site 206, New Caledonia Basin}

At Site 206 (Figure 2) this feature occurs, as an angular unconformity, in Sample 206C-15-2, 25.5-27.5 cm, which was cored at a subbottom depth of 613 meters below a water column of 3201 meters. The sediment immediately underlying the unconformity is a lithified greenish gray bioturbated radiolarian nannofossil ooze with relict bedding. This bedding, as judged from photographs of the archive half of the core, has a consistent apparent dip of about $10^{\circ}$. The uppermost 3 to $5 \mathrm{~cm}$ is noticeably darker in hue and could conceivably represent some form of residual deposit. Other conspicuous features include a ?Zoophycos trace (at $37 \mathrm{~cm}$ ) and an apparently cemented compaction crack (at $40 \mathrm{~cm}$ ). Both of these features have apparent dips subparallel to the bedding. A sample taken at $38 \mathrm{~cm}$ yielded, in addition to abundant siliceous microfossils (especially diatoms), a moderately diverse and abundant, but poorly preserved, calcareous nannoflora. This assemblage, which has been subjected to selective dissolution and overgrowth, appears to have been deposited in the vicinity of the lysocline from a mid subtropical oceanic near-surface water mass. Although the relevant taxa are sparse, this nannoflora conforms to both the Reticulofenestra bisecta Zone of Edwards (1971) and the Discoaster saipanensis (NP17) Zone of Martini (1971). Thus, it is considered to be of Late Eocene 1/5 (early Kaiatan) age.

The unconformity, which was recovered intact (Figure 2 ), is a moderately conspicuous abrupt undulating feature having a $20^{\circ}$ apparent dip in the same general direction as the underlying and overlying sediments. Since this feature has relief of the order of $0.5 \mathrm{~cm}$ and a steeper apparent dip than the underlying sediment, it is here considered to be an angular unconformity. However, it is probable that the angularity is only of local extent since this site is situated adjacent to a small elongate hill and both the underlying and overlying cores contain numerous indications of compaction and slumping. The unconformity did not give a distinctive seismic reflection.

The overlying sediment is a lithified light gray foraminifera- and clay-rich nannofossil ooze, which is in part bioturbated and in part well bedded with more or less regularly spaced greenish gray laminations. The basal $8 \mathrm{~cm}$ is indistinctly bedded with an apparent dip of $20^{\circ}$ in the same general direction as the unconformity. The overlying well-bedded interval appears to have been rotated relative to the underlying sediment prior to being photographed since it has a consistent apparent dip of $13^{\circ}$. Shipboard measurements on this latter part of the core indicate a true dip of about $30^{\circ}$. A sample taken at $6 \mathrm{~cm}$ yielded a moderately diverse and abundant, but poorly preserved, nannoflora without associated siliceous microfossils. This assemblage, like that in the underlying Late Eocene sample, 


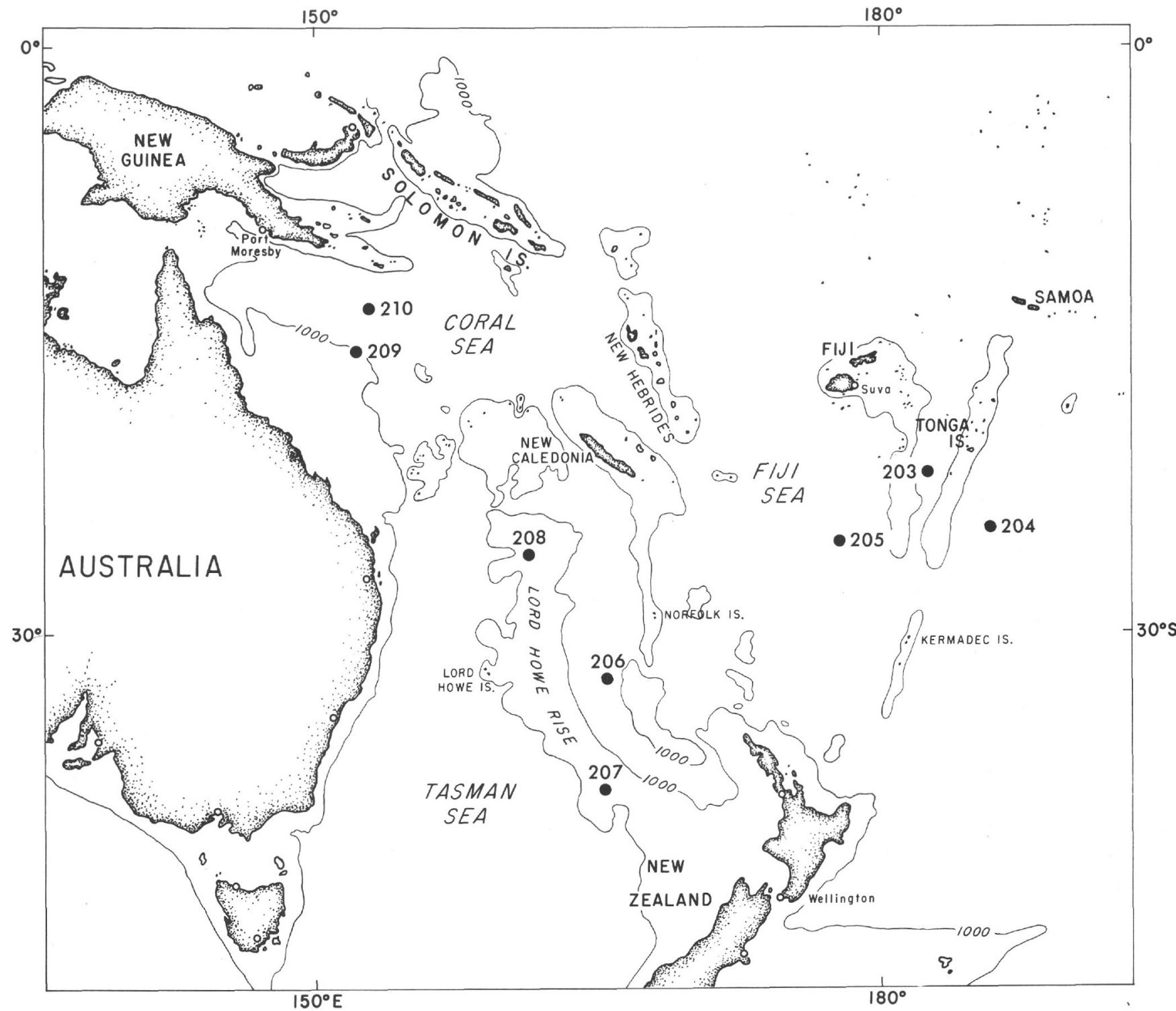

Figure 1. Locality map showing Leg 21 sites.

is considered to have been deposited in the vicinity of the lysocline from a mid subtropical oceanic near-surface water mass. Although the relevant taxa are sparse, this nannoflora conforms to both the combined Cyclococcolithus neogammation and Syracosphaera clathrata zones of Edwards (1971) and the Sphenolithus predistentus (NP23) Zone of Martini (1971). Thus, it is considered to be of mid Oligocene $1 / 2$ (mid Whaingaroan to early Duntroonian) age. This assemblage does not contain any obvious reworking from the underlying Eocene sediments. The foraminifera of the immediately overlying cores indicate a late Whaingaroan age judging by the occurrence, in 206C-11-CC, of Rotaliatina and the consistent absence of Globigerina angiporoides (see site report, Chapter 6).

\section{Site 207, Southern Lord Howe Rise}

The unconformity is known to occur at this site, which underlies a water column of 1393 meters, but its exact location is uncertain due to complications. Briefly the relevant part of the sequence, which was continuously cored, is as follows:

\begin{tabular}{|c|c|c|}
\hline Hole 207A & Depth & Stage and Age \\
\hline $9-1$ to $9-3$ & 119 to 123 & Lillburnian (mid Miocene) \\
\hline $9-4$ to $9-5(105 \mathrm{~cm})$ & 124 to 126 & Clifdenian (mid Miocene) \\
\hline \multicolumn{3}{|c|}{ Regional unconformity? (Possibility A) } \\
\hline $\begin{array}{l}9-5(105 \mathrm{~cm}) \text { to } 9-\mathrm{CC} \\
10-1 \text { to } 10-\mathrm{CC}\end{array}$ & $\begin{array}{l}126 \text { to } 128 \\
133 \text { to } 139\end{array}$ & $\begin{array}{l}\text { Kaiatan (Late Eocene) } \\
\text { Lillburnian (mid Miocene) }\end{array}$ \\
\hline \multicolumn{3}{|c|}{ Regional unconformity? (Possibility B) } \\
\hline $11-1$ to $11-\mathrm{C}$ & 142 to 151 & Bortonian (mid Eocene) \\
\hline
\end{tabular}

All of this interval has, like the underlying and overlying intervals, been subjected to considerable disturbance during drilling, but only the Core 10 microfossil assemblages are 
out of sequential order. The case for possibility $\mathbf{A}$ is based on two assumptions: (a) that Core 10 represents sediment injected from above the unconformity (i.e., it is a drilling artifact) and (b) that the 133 to 142 meter interval contains Eocene sediments which were not sampled (i.e., this interval was punched through during the 30 minutes or so between commencing to pull Core 10 out and spudding in Core 11). Furthermore, the relatively high deposition rate known to occur in the underlying mid Eocene sediments would necessarily require the acceptance of either a much slower Late Eocene depositional rate or an unsampled disconformity.

The case for possibility B is based entirely on the hypothesis that the 126 to 139 meter interval results from slumping subsequent to the formation of the unconformity. It also involves the implicit assumption that, at least in the immediate vicinity of this site, the unconformity is probably angular and cuts across sediments ranging in age from Bortonian to Kaiatan (late mid to early Late Eocene). Such an angularity, and, indeed, such an exceptionally large unconformity, is consistent with this site's location close to the Bellona Gap-an obvious route for bottom or intermediate waters moving between the Tasman and New Caledonia basins.

Unfortunately, the available data does not allow a decision to be made as to which set of arguments is correct. However, for site report purposes (see Chapter 7), possibility B was accepted, largely on the grounds that a seismic reflector, probably derived from a chert interval (see below), occurs at this horizon. A summary of the relevant sediments recovered is given below.

Core 11 consists of a creamy (in consistency) white homogenous foraminiferal nannofossil ooze, which in the upper part contains scattered broken fragments of light gray chert. These fragments could well be autochthonous. However, their observed stratigraphic position coupled with the absence of chert in the underlying and overlying sediments suggests that they may have originally formed a protective lag gravel immediately below the unconformity (sensu possibility B). Samples taken at 207A-11-2, $30 \mathrm{~cm}$, and 207A-11-CC yielded diverse, abundant, and moderately well preserved nannofossils. These are considered to have been deposited at midbathyal depths from a warm subtropical oceanic near-surface water mass. They conform to the combined Reticulofenestra hampdenensis and Discoaster distinctus zones of Edwards (1971), which are probably correlative with the Chiphragmalithus alatus (NP15) Zone of Martini (1971). Consequently, they are considered to be of mid Eocene 6/7 (early to mid Bortonian) age.

Core 10 consists of a creamy (in consistency) pale yellow foraminiferal nannofossil ooze with streaks of white. At the top of Section 2, a horizontal white horizon (bed?) of similar material occurs. Samples taken at 207A-10-1, 120 $\mathrm{cm}$; 207A-10-3, $25 \mathrm{~cm}$; and 207A-10-CC yielded diverse, abundant, and moderately well preserved nannofloras containing minor reworking from Eocene sediments. These assemblages, like those which underlie, appear to have been deposited at mid-bathyal depths from a mid subtropical oceanic water mass. In containing rare specimens of the name bearer, these nannofloras are considered to be more or less correlative with the Sphenolithus heteromorphus (NN5) Zone of Martini (1971). Consequently, they may well be of mid Miocene 1/4 (Langhian) age. The associated foraminifera indicate a late Lillburnian (mid Miocene) age.

Core 9 contains two similar lithologies which have a somewhat oblique marked junction at 207A-9-5, 105 $\mathrm{cm}$-the regional unconformity sensu possibility $\mathrm{B}$. The lower, 2-meter-thick, interval consists of a creamy (in consistency) white foraminiferal nannofossil ooze with streaks of pale yellow. The upper interval, some 7 meters thick, consists of a creamy (in consistency) pale yellow nannofossil foraminiferal ooze which grades up into a yellowish white homogenous foraminiferal nannofossil ooze. All of the samples taken from the core yielded diverse, abundant, and moderately well preserved nannofloras which, like those which underlie, are considered to have been deposited at midbathyal depths from mid subtropical oceanic water masses. The nannofloras obtained from the lower lithology, despite very minor apparent contamination from the overlying sediments, clearly conform to the Chiasmolithus oamaruensis Zones of both Edwards (1971) and Martini (NP18, 1971). According, they are considered to be of Late Eocene 2/5 (mid Kaiatan) age. Of the nannofloras obtained from the upper lithology, most contain Sphenolithus heteromorphus, but those from Sections 1 and 2 lack this taxon. Accordingly, these assemblages, which contain only very minor reworking, are considered to be approximately correlative with the Sphenolithus heteromorphus (NN5) and Discoaster exilis (NN6) zones, respectively, of Martini (1971). The associated foraminifera indicate a similar sequence of events for this core: the Kaiatan (Late Eocene) being overlain by Clifdenian (mid Miocene) faunas in Sections 4 and 5 and followed by (younger) Lillburnian (mid Miocene) assemblages.

\section{Site 208, Northern Lord Howe Rise}

At this site (Figure 3), the Eocene-Oligocene unconformity occurs at 208-27-3, $89 \mathrm{~cm}$, either as a disconformity or a paraconformity. This sample was cored at a subbottom depth of 487 meters below a water column of 1554 meters. The sediment immediately underlying the unconformity is a greenish gray bioturbated sponge spicule and radiolarian-rich nannofossil chalk with relict bedding which has an apparent dip of $5^{\circ}$ or less. Disseminated glauconite is present in minor quantities. No lithologic change is discernible in the uppermost few centimeters. A sample taken at $87 \mathrm{~cm}$ (probably $90 \mathrm{~cm}$ in Figure 3) yielded, in addition to common siliceous microfossil fragments, a diverse and abundant, but poorly preserved, calcareous nannoflora. This assemblage appears to have been deposited at midbathyal depths from a warm subtropical oceanic water mass. Both this nannoflora and the much better preserved assemblage in 208-27-CC conform to the upper part of the Chiphragmalithus cristatus Zone of Edwards (1971), which is an approximate correlative of the Chiphragmalithus alatus (NP15) Zone of Martini (1971). Thus, both nannofloras are considered to be of mid Eocene 5/7 (late Porangan to early Bortonian) age. The associated foraminifera indicate a Porangan age. 


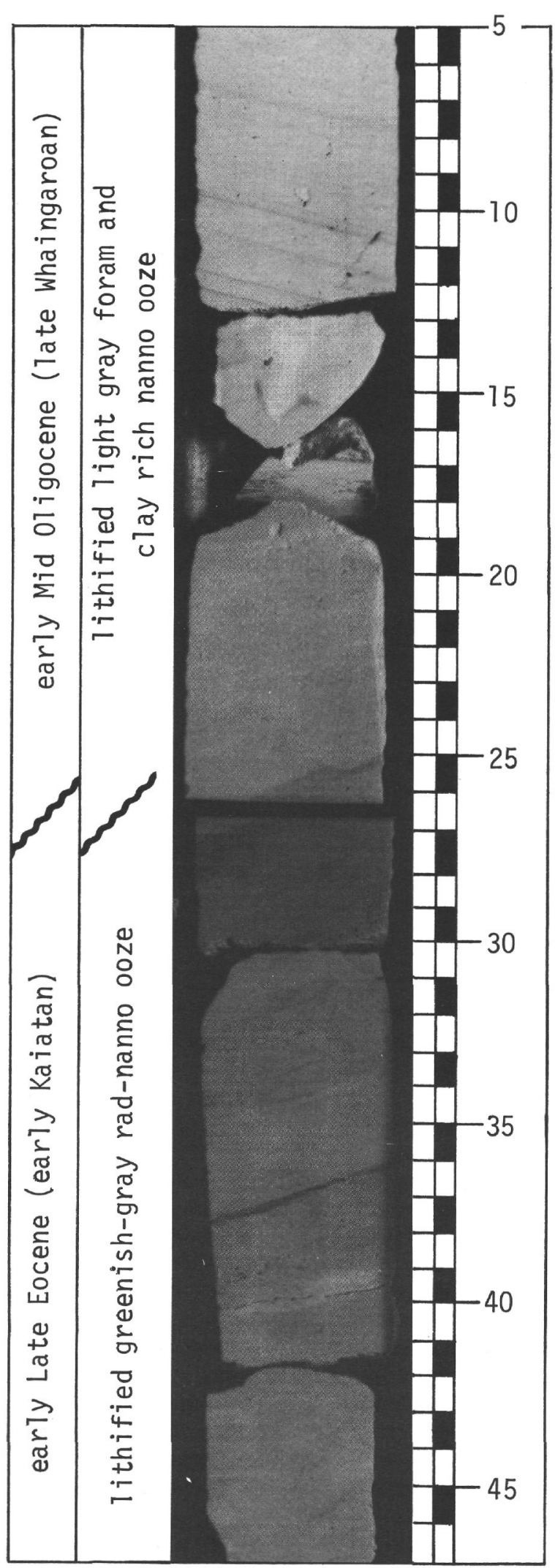

Figure 2. The Eocene-Oligocene regional unconformity at Site 206 (New Caledonia Basin) as recovered in 206C-15-2. Approximately one-half natural size.

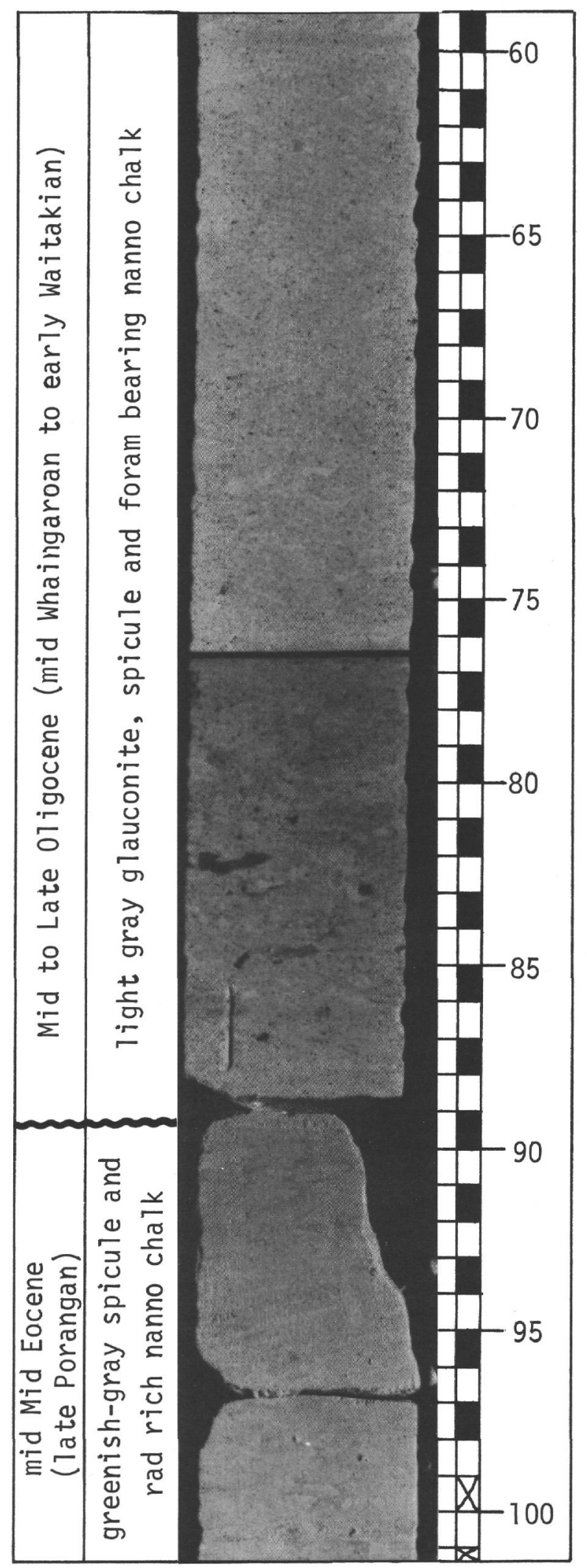

Figure 3. The Eocene-Oligocene regional unconformity at Site 208 (northern Lord Howe Rise) as recovered in 208-27-3. Approximately one-half natural size. 
The unconformity was not recovered intact, but in all probability, only a centimeter or two has been lost-the maximum possible loss being about 1 meter. The shape of the immediately underlying part of the core is suggestive of damage and loss of the contact during drilling. Since the overlying and underlying sediments have essentially parallel bedding, this feature must either be a disconformity or a paraconformity. A strong seismic reflector occurs at this horizon.

The overlying sediment is a light gray bioturbated glauconite, sponge spicule, and foraminifera-bearing nannofossil chalk with numerous lighter colored blotches and suggestions of horizontal bedding. Most of the glauconite is present as disseminated particles, but conspicuous clumps occur in the lower $6 \mathrm{~cm}$. The intense bioturbation evident in this interval does not appear to be related to that present in the underlying sediment. A sample taken at $83.5 \mathrm{~cm}$ (probably $86 \mathrm{~cm}$ in Figure 3) yielded, in addition to siliceous microfossil debris, a moderately diverse and abundant, but poorly preserved, nannoflora. This assemblage, which has been subjected to considerable overgrowth, appears to have been deposited at bathyal depths from a mid subtropical oceanic water mass. It clearly conforms to the Discoaster deflandrei Zone of Edwards (1971) and thus appears to be of Late Oligocene (late Duntroonian to early Waitakian) age. However, this conclusion is based on the absence of Chiasmolithus oamaruensis, the occurrence of which has yet to be demonstrated at this latitude, and a conservative age assessment of mid to late Oligocene (mid Whaingaroan to early Waitakian) would seem advisable. After a long search, specimens of Sphenolithus distentus and S. predistentus were found. The overlying Sample 208-27-2, $30 \mathrm{~cm}$, yielded extremely sparse $S$. ciperoensis. Thus, it would seem likely that the whole of the upper part of Core 27 is correlative with the Sphenolithus distentus (NP24) Zone of Martini (1971) and is of mid Oligocene $2 / 2$ to Late Oligocene $1 / 2$ age. Reworking from the underlying Eocene sediments is minor in both samples.

\section{Site 209, Queensland Plateau}

At this site, the unconformity probably occurs between 209-14-CC and 209-15-1 at a subbottom depth of about 140 meters (limits: 110 to $150 \mathrm{~m}$ ) and below a water column of 1438 meters. Its biostratigraphic recognition is greatly complicated by the uncertainties introduced by Core 209-14. Briefly, this core consists of a friable light greenish gray silty sand grade foraminifera-rich calcic ooze which appears to represent an intimate mixture of downhole caved, in situ (Late Oligocene) and reworked (Eocene) sediments (see site report). The underlying sediments are represented by soft grayish homogeneous silty sand grade foraminiferal calcic oozes which often have been silicified or irregularly replaced by chert. Minor constituents include ascidian sclerites, echinoderm fragments, nannofossils, and glauconite. Samples taken from 209-15-1, $75 \mathrm{~cm}$, and 209-15-CC yielded very small poorly preserved nannofloras. These, taken in conjunction with the ones which underlie, imply upper bathyal or outer sublittoral deposition, during Late Eocene $1 / 5$ to $3 / 5$ (Kaiatan) time, from a warm subtropical offshore water mass. The foraminiferal evidence is consistent with these conclusions.
The unconformity was not knowingly recovered. It probably occurs in the uncored interval between 209-14-CC and 209-15-1 but could conceivably occur within the former core (see above). A sharp contact overlain by sediments initially largely derived from the local reworking of older sediments seems a distinct possibility. The contact is not marked by a seismic reflector.

The overlying Core 209-13 is only represented by a corecatcher sample. It consists of a soft nannofossil-bearing (i.e., winnowed) calcic foraminiferal ooze, which contains a small moderately well preserved nannoflora. This assemblage is correlated with the Late Oligocene $2 / 2$ part of the Sphenolithus ciperoensis (NP25) Zone of Martini (1971) and is not younger than the late Duntroonian to early Waitakian Discoaster deflandrei Zone of Edwards (1971). The associated earliest Miocene foraminifera imply deeper, more open-water, conditions than those under which the Eocene was deposited.

\section{Site 210, Coral Sea Basin}

At this site, the unconformity occurs, probably as an angular unconformity, between 210-34-CC and 210-35-1 at a subbottom depth of 539 to 542 meters below a water column of 4650 meters. The sediment immediately underlying the unconformity is (Core 35) a light olive gray clay-bearing calcic nannofossil chalk with moderate mottling and scattered small chert nodules throughout. The bedding dips at about $20^{\circ}$. This core contains moderately diverse and abundant, but very poorly preserved, nannofloras, which clearly were deposited at abyssal depths close to the calcium carbonate compensation depth from a subtropical near-surface water mass. Despite reworking (?minor) from older Eocene sediments, these assemblages conform to the Reticulofenestra bisecta Zone of Edwards (1971), which is normally assigned a Late Eocene 1/5 (early Kaiatan) age. However, a Late Eocene 1/5 to 3/5 (Kaiatan) age assessment seems advisable for reasons similar to those given in the Site 209 report (Chapter 9). This is consistent with the relative thickness of this interval compared with the rapid upward slowdown in the deposition rate of the underlying late mid Eocene sediments implied by their nannofossil biostratigraphy. Alternatively, it could reflect minor surficial slumping prior to the overlying Oligocene sediments being deposited since Cores 35 to 37 have upward increasing dips. The associated sparse and poorly preserved foraminifera and Radiolaria have been assigned mid Eocene ages.

The unconformity was not recovered, but the attitudes of the underlying and overlying sediments clearly indicate an angular unconformity of at least local extent. This feature is not marked by a seismic reflector at Site 210 . However, if it is assumed that the overlying reflector 3 is time transgressive, the underway profile can be interpreted to indicate that sedimentation at this site recommenced later than the immediately adjacent (topographically lower) areas. Such an interpretation is consistent with the site report conclusion that disturbance of the basin floor occured during the time span of the unconformity.

The overlying sediment consists (Core 34) of yellowish clay-bearing calcic nannofossil chalk having intensive mottling throughout and possessing a dip that appears to be close to horizontal. These sediments contain low diversity 
and very poorly preserved, but abundant, nannofloras which clearly have similar paleo-environmental implications to those of the underlying core. Taken at face value, the core catcher assemblage conforms to the Early Oligocene 1/2 Ericsonia subdisticha (NP21) Zone of Martini (1971) and the overlying assemblages to his Early Oligocene 2/2 Helicopontosphaera reticulata (NP22) Zone. Put another way, these assemblages conform to the Reticulofenestra placomorpha Zone (early Whaingaroan) of Edwards (1971) but probably also include sediments equivalent to the upper part of his latest Runangan to early Whaingaroan Blackites rectus Zone. However, for the site report purposes (q.v.) all of these assemblages were assigned to the Early Oligocene 2/2 Helicopontosphaera reticulata (NP22) Zone on the grounds that the two specimens of Cyclococcolithina formosa observed in the core catcher almost certainly represent minor reworking or contamination. At the present time, the writer is by no means certain whether the very rare occurrence of Reticulofenestra placomorpha throughout this core is also due to a similar cause. However, no other species which might have been reworked have been noted in these assemblages and similar situations have been observed in certain New Zealand assemblages (writer's observations). Therefore, at the moment, a mid Oligocene age assessment of this core is unwarranted. No Radiolaria and only a few indeterminate foraminifera occur in this interval.

\section{Age}

In all of the sequences described above, the unconformities invariably include all of the upper, latest Kaiatan and Runangan, part of the Late Eocene (Table 1). It is highly probable (but see Sites 209 and 210 above) that the unconformities also invariably include both the underlying, late Kaiatan, part of the early Late Eocene and the overlying, basal Whaingaroan, part of the early Early Oligocene. Furthermore, with the notable exception of Site 210 , all of the unconformities additionally span all of the upper part of the Early Oligocene plus at least the basal part of the mid Oligocene, i.e., all of the early Whaingaroan. If Site 210 is disregarded, the strongest evidence for the upper age limit of the unconformity is provided by Site 206, where undoubted late Whaingaroan sediments were recovered. Put another way, the time span common to these unconformities undoubtedly covers 5 million years, probably extends over 10 million years, and possibly up to 15 million years. These calculations are based on the time scale given by Berggren (1969).

The situation outlined above is compelling evidence that a common event, or set of events, caused a regional unconformity to develop over a vast area. However, it is important to emphasize that although the broad age limits are known, the sequences, with the possible exception of Site 210 , give no clue as to the exact age, length of time, or number of events or phases involved in the formation of the unconformities. Despite this, it is tempting to speculate that the main phase was centered on either the Runangan-Whaingaroan (Eocene-Oligocene) or early-late Whaingaroan boundaries. In other words, it caused the sudden extinction of either Globigerapsis index (and Discoaster saipanensis) or Globigerina angiporoides or abruptly truncated the upper range of these species by erosion.

\section{Possible Southwest Pacific Correlatives}

The unconformity was not recognizable as such at Site 204, the only other Leg 21 sequence to reach this stratigraphic level. However, the biostratigraphic control of this abyssal southwest Pacific Basin sequence is exceptionally poor. Consequently, there is no way of determining whether the abrupt contact between questionable Oligocene abyssal and the underlying questionable Cretaceous tuffaceous sandstone and conglomerate, recovered in 204-5-CC, represents this feature or not. Information obtained by Johnson et al. (1972) from cores taken near Samoa, some $12^{\circ}$ to the north of Site 204 , suggests that the regional unconformity may be present at both localities.

Of the other two sequences drilled during Leg 21, one, Site 203 in the Lau Basin, consisted only of late Neogene sediments. The other, Site 205 in the South Fiji Basin, has some relevance in that in situ latest mid Oligocene nannofossil chalk was cored prior to the hole being vacated some 200 meters above the seismic basement. Clearly, if the regional unconformity is present in the unsampled part of the sequence, the age given above places some limit on its time span.

Either this unconformity or an approximately age equivalent feature appears to be present in Papua-New Guinea (Davies and Smith, 1971, p. 3306). It may also be present in the Malaita Group of the Solomon Islands (McTavish, 1966, tables 2, 4, 6), but this is by no means certain since detailed species lists were not provided for the samples studied. It is also possible that this feature is present in Fiji (Rodda, 1967) and New Caledonia (Lillie and Brothers, 1970).

In New Zealand, the possible existence of mid Cenozoic regional unconformities has been the subject of much controversy and speculation for almost a century, but with remarkably little detailed investigation. Hutton (1877, pp. 31 and 44) appears to have provided the first spark. Most of these features consist of a bored and phosphatized surface disconformably overlain by glauconite and pebble-rich sediments, but, at some localities, pebbles predominate. Many authors have noted their approximate coincidence with the culmination of the New Zealand Late Cretaceous and Paleogene transgression, for example MacPherson (1946, p. 18), Wellman (1953, fig. 6), Gage (1957, p. 18) and Wilson (1963, p. 37). Despite this, no diachroneity, local or regional, of these unconformities has yet been demonstrated, perhaps because they are well below the limits of present biostratigrpahic resolution.

By far the most conspicuous of these features is that which usually immediately underlies Duntroonian (Late Oligocene) sediments over much of New Zealand, for examples see Thompson (1920; 1926), Mason (1948, fig. 2), Gage (1957, pp. 48-50), Gair (1959, p. 272 and 1962, Fig. 3), Andrews (1963), Ridd (1964, fig. 5), Barrett (1967, pp. 1019-1022), Hornibrook (1967a) and Vella (1967a). However, in detail, the ages of both the underlying and overlying sediments vary significantly, and there is growing field evidence, largely unpublished, that at many localities this feature results from the complex merging of several 
TABLE1

The Biostratigraphic and Chronostratigraphic Extent of the Eocene-Oligocene

Regional Unconformity (Correlations Based on Edwards, 1971, figs. 6 and 7)

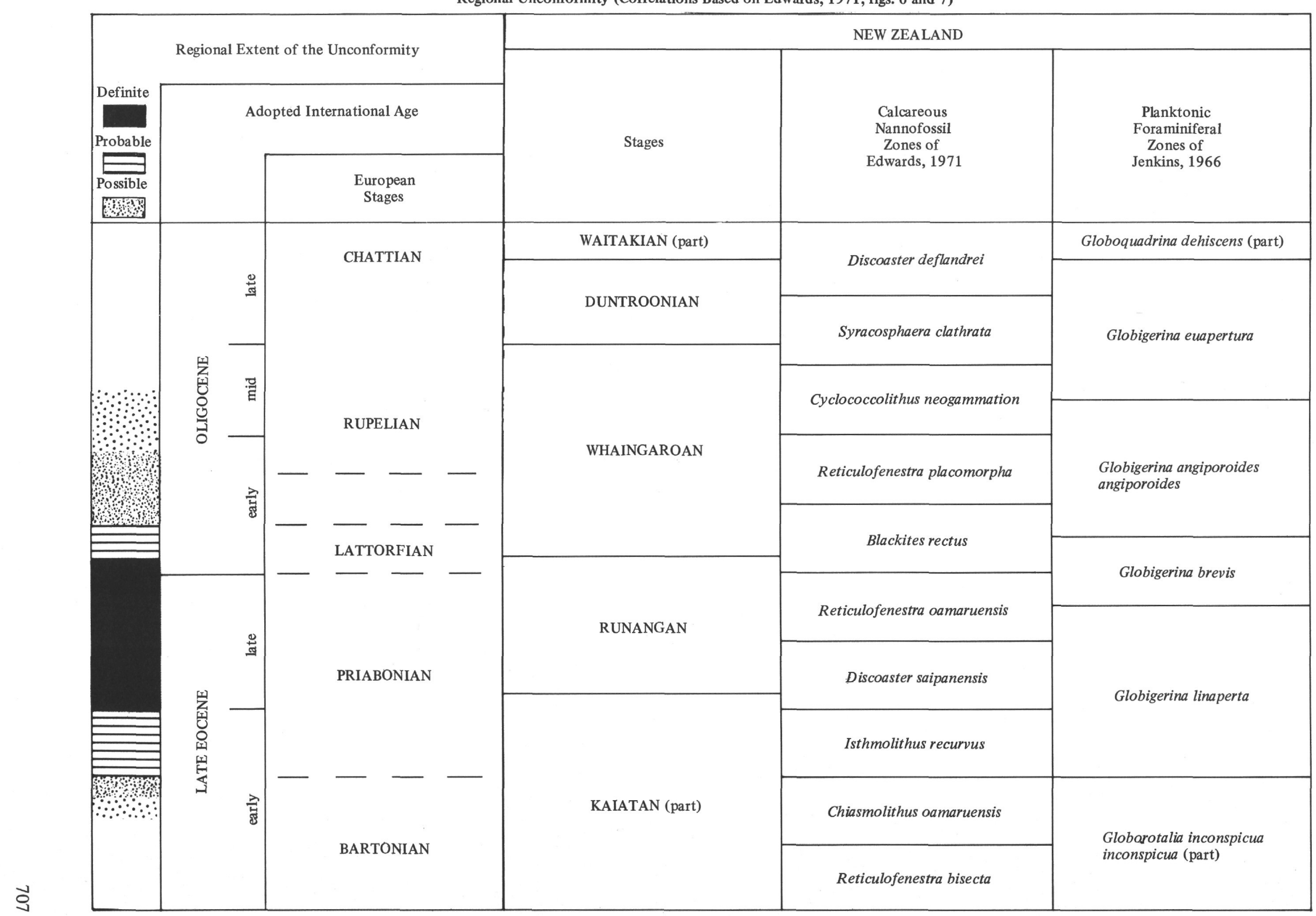


distinct disconformities. These are suspected to be of "basal" Late Whaingaroan (mid Oligocene; see Hornibrook, $1967 b$, p. 1160; Vella, 1967b, p. 1163; and Carter and Landis, 1972), "basal" Duntroonian (Late Oligocene) and early Waitakian (latest Oligocene; Vella, 1967a, table 5-but also see Vella, 1967b, p. 1163) age. The latter disconformity may sometimes merge with the overlying "well known" late Waitakian (earliest Miocene) disconformity (see Hornibrook, 1967a, p. 465 and fig. 2 for a possible example). Furthermore, at some localities all of these disconformities appear to merge; for progressive stages in this merging compare Hornibrook (1967a, fig. 1) with Gage (1957, p. 48 plus columns S136/3 to 8) and Benson (1969, p. 9). Of these disconformities, only the "basal" late Whaingaroan one can, for age reasons, be considered as a possible correlative of the Leg 21 regional unconformity. However, all of these disconformities will have to be documented to a much greater degree than at present before their time and space relationships are fully understood. The same is true of the numerous Late Eocene to Early Miocene sedimentary cycles postulated by Vella (1967a and b).

Apart from Site 209 on the Queensland Plateau, no marine sequences of equivalent age have as yet been described from the Australian eastern seaboard. However, it is interesting to note that the Capricorn Basin (Palmieri, 1971) became marine about the same time as deposition recommenced at Site 209. The southern seaboard contains a number of marine sequences suitable for determining whether or not the Leg 21 feature occurs. However, to date, Australian investigators have not even hinted at the possibility of a regional unconformity existing in these sequences. But both Vella (1967a) and Carter and Landis (1972) have speculated that such features are present. The best possibility appears to be at the base of the Oligocene (Late Oligocene?) Janjukian Stage (compare Ludbrook, 1967, fig. 3 and Ludbrook and Linsay, 1967, fig. 2). But until more information is available on these sequences, caution in such speculations would seem advisable. Indeed, such is probably true of all the possible correlatives listed above.

\section{THE PALEOCENE-EOCENE UNCONFORMITY}

\section{Occurrence}

This widespread feature has been recognized in Leg 21 Tasman Sea Holes 206C, 207A, and 208, which were spudded in at mid to lower bathyal (1400 to $3200 \mathrm{~m}$ ) depths, separated by up to $10.8^{\circ}$ of latitude and $4.2^{\circ}$ of longitude (Figure 1). Descriptions of the situations observed at each location are as follows.

\section{Site 206, New Caledonia Basin}

At this site the unconformity occurs, probably as an angular unconformity, between 206C-19-3 $131 \mathrm{~cm}$ and the immediately underlying 206C-19-CC. The latter was cored at a subbottom depth of 692 meters below a water column of 3201 meters. The core catcher sediment immediately underlying the unconformity consists of a lithified light greenish gray nannofossil-rich "clay" (grade). The underlying two cores, the lowest taken at this site, consist of moderately to highly lithified nannofossil-rich "clays," "claystones," and calcitic limestones which have been intensively disturbed by slumping. Green to greenish gray chert is present, probably in bands, in Core 21. The nannofossil assemblages taken from these sediments have been discussed in detail in the site report (Chapter 6). Briefly, they indicate that most of this interval is in normal sequential order. However, those from the basal part of Core 21 appear to be slightly younger (Mid Paleocene 1/3, basal mid Teurian) than the 206C-19-CC assemblage which conforms to the lower, Early Paleocene 5/5 (latest early Teurian), part of the Fasciculithus tympaniformis Zones of both Edwards (1971) and Martini (NP5, 1971). Many of the nannofossil assemblages obtained from the 19-CC to 21-CC interval contain obvious reworking, and others are highly fragmented. Clearly, they were transported to this site by bottom currents. The associated foraminifera imply deposition during early Paleocene time from somewhat shallower depths than the present day deposition.

The unconformity may have been recovered intact. However, the contact has not been observed, possibly because it was "lost" during the necessary separation of the core catcher portion from the remainder of Core 19. The apparent occurrence of an age inversion in the underlying sediments suggests that, locally at least, the unconformity is angular. Such a conclusion is also consistent with both the location of this site and the abundant indications of slumping evident in the underlying and overlying sediments (see the Site 206 Eocene-Oligocene unconformity description above). The unconformity did not give a distinctive seismic reflection.

The overlying sediment mostly consists of a lithified light greenish gray clay and foraminifera-bearing calcitic rich nannofossil ooze which has been strongly disturbed by slumping. It is often faintly mottled with greenish white sediment and contains a few scattered lumps of yellowish brown or greenish gray chert. The uppermost $57 \mathrm{~cm}$ of Core 19 differs slightly in being speckled with fragments of greenish black material. The abundant and diverse, but very poorly preserved, nannofloras obtained from Sections 2 and 3 conform to both the Early Eocene 4/5 (early Mangaorapan) Discoaster lodoensis Zone of Edwards (1971) and the Marthasterites tribrachiatus (NP12) Zone of Martini (1971). These nannofloras contain common to abundant Zygrhablithus bijugatus and thus appear to have been deposited, from subtropical near-surface waters, at depths well above the lysocline. In contrast, the overlying Sample 206C-19-1, $16 \mathrm{~cm}$ yielded a mid Eocene 5/7 (late Porangan to early Bortonian) nannoflora which, like the overlying mid Eocene sediments, contains only sparse $Z$. bijugatus. Thus, this latter sample is considered to have been deposited in the vicinity of the lysocline just after the sedimentary record recommenced, following an early to mid mid Eocene disconformity at $206 \mathrm{C}-19-1,57 \mathrm{~cm}$. The foraminifera yielded similar age (Mangaorapan overlain by Bortonian) and environmental (deeper than the Paleocene) implications. Consequently, it seems probable that Site 206 was subjected to relatively rapid downdrop, from midbathyal to lower bathyal depths, during early Cenozoic time. No conspicuous evidence for subsidence is provided by the Oligocene and younger microfossils. Thus, the 
implied pattern of downdrop at Site 206 closely matches that given by Sclater et al. (1971) for subsidence following the termination of active sea floor spreading.

\section{Site 207, Sou thern Lord Howe Rise}

This feature is known to occur in the middle to lower part of Core 207A-26 at this site, i.e., at a subbottom depth of about 285 meters below a water column of 1393 meters. Furthermore, the unconformity is known to involve the loss or nondeposition of latest Paleocene to early Eocene sediments. But, despite this, its exact position, and thus the nature of the contact, is uncertain due to complications. In summary, the lithostratigraphy and biostratigraphy of this core is as follows (in downward sequential order):

1) A highly deformed ca. $175 \mathrm{~cm}$-thick interval, down to about $140 \mathrm{~cm}$ in Section 2, containing a moderately well sorted layer of very light gray chert fragments, several layers of soupy light greenish gray foraminifera-bearing nannofossil ooze (with or without abundant chert fragments), and a thin lense of nannofossil-bearing ash. No microfossil samples were taken from this interval because of its obviously much disturbed, and probably downhole caved, nature.

2) A relatively undisturbed 80 cm-thick interval, between 207A-26-2, $140 \mathrm{~cm}$ and 207A-26-3, $70 \mathrm{~cm}$, of semilithified light greenish gray becoming (grading down into) bluish white mottled foraminifera-bearing nannofossil ooze with a thin chert horizon. Three samples taken for nannofossils, at $145 \mathrm{~cm}$ in Section 2 plus $25 \mathrm{~cm}$ and $66 \mathrm{~cm}$ in Section 3, yielded abundant and diverse, but poorly preserved, nannofloras. These were clearly deposited at upper bathyal depths from a warm subtropical near-surface water mass and conform to the upper, Early Eocene 3/5 (late Waipawan), part of the Chiasmolithus grandis Zone of Edwards (1971). This zone is probably a correlative of the Discoaster binodosus (NP11) Zone of Martini (1972). The central sample contains undoubted common reworking from the underlying Late Paleocene, but reworking is not conspicuous in the other two samples.

3) A probably moderately disturbed ca. $250 \mathrm{~cm}$-thick interval, between 207A-26-3, $70 \mathrm{~cm}$ and 207A-26-CC, of semilithified light greenish gray mottled foraminiferabearing nannofossil ooze without associated chert. This part of the core has been fragmented, probably during drilling, into numerous disk-shaped segments. The five samples taken for nannofossils from this interval yielded abundant and very diverse, but poorly (Section 3) to moderately (Section 4 and the corecatcher) preserved, nannofloras. These assemblages, which clearly indicate similar environmental conditions to those in the overlying interval, have been discussed in detail in the site report (Chapter 7). Briefly, a nannofossil assemblage indicative of the upper, Early Eocene 3/5 (late Waipawan), part of the Chiasmolithus grandis Zone of Edwards (1971) occurs at 207A-26-4, $25 \mathrm{~cm}$. Thus, it is sandwiched between assemblages correlated with the Late Paleocene 2/3 (latest Teurian to basal Waipawan) Discoaster mediosus Zone of Edwards (1971) and his Late Paleocene 1/3 (late Teurian) Discoaster multiradiatus Zone. If the anomalous central assemblage and the presence of minor contamination are discounted, the sequence becomes a normal succession conforming to the Discoaster multiradiatus (NP9) Zone of Martini (1971). However, the solution of this problem is not that simple because the foraminifera also imply a normal sequence, but would place all of the interval above the corecatcher in the Early Eocene. Since these foraminiferal assemblages also contain a considerable amount of Late Paleocene (late Teurian) contamination, one obvious way of resolving the apparent conflict between the age assignments provided by the two groups is to assume that the unconformity occurs near the base of Core 26 , and that the recommencement of sedimentation in Early Eocene 3/5 time initially involved the substantial reworking of adjacent Late Paleocene nannofossil ooze sediments. If the above assumptions are correct, this feature is either a disconformity or an angular unconformity involving all of the Late Paleocene 2/3 to Early Eocene 2/5 (latest Teurian to mid Waipawan) interval. However, since much of this core has clearly been subjected to drilling disturbance, it would be just as reasonable to assume that the age inversions and "contamination" are artifacts. If such is the case, then it would be logical to place this feature, as a paraconformity or disconformity involving all of the Late Paleocene 3/3 to Early Eocene 2/5 (early mid Waipawan), at 207A-26-3, $70 \mathrm{~cm}$. At the present time, there is no means of determining which hypothesis is correct. The writer currently favors the former thesis but adopted the latter for site report purposes. Another, much clearer, example of the value of supplementing the nannofossil evidence with that provided by other microfossil groups is given below under the MesozoicCenozoic boundary. The unconformity did not give a distinctive seismic reflection.

\section{Site 208, Northern Lord Howe Rise}

At this site (Figure 4), the unconformity probably occurs, as either a disconformity or a paraconformity, at 208-29-1, $102 \mathrm{~cm}$, which was cored at a subbottom depth of 540 meters below a water column of 1554 meters. The uncertainty regarding the exact position and nature of this feature largely results from inadequate paleontologic sampling, which merely allows a location within the 208-29-1, 47-109 $\mathrm{cm}$ interval to be deduced. The 2-meter-thick bed underlying the presumed position of the unconformity consists of a very hard light-colored nannofossil chalk which has been intensively bioturbated. The bioturbation is expressed as mottling which is very consistently elongated subhorizontally to the core. No bedding planes were observed within the above interval, or even within the core, but its overall appearance provides no reason to doubt that this bed has a near horizontal attitude similar to that evident throughout the Site 208 sequence. The soft horizons at $108 \mathrm{~cm}$ and $122 \mathrm{~cm}$ (Figure 4) are speculated to be infilling younger sediment resulting from trace fossil activity during, or subsequent to, the unconformity. If, as the nannofossil evidence given below can be construed as suggesting, this interpretation is correct, then the bed must have been semiconsolidated prior to the overlying sediment being deposited. The three samples taken for nannofossils from this bed yielded abundant and moderately diverse, but poorly preserved, assemblages. These nannofloras conform to the Mid 
A. R. EDWARDS

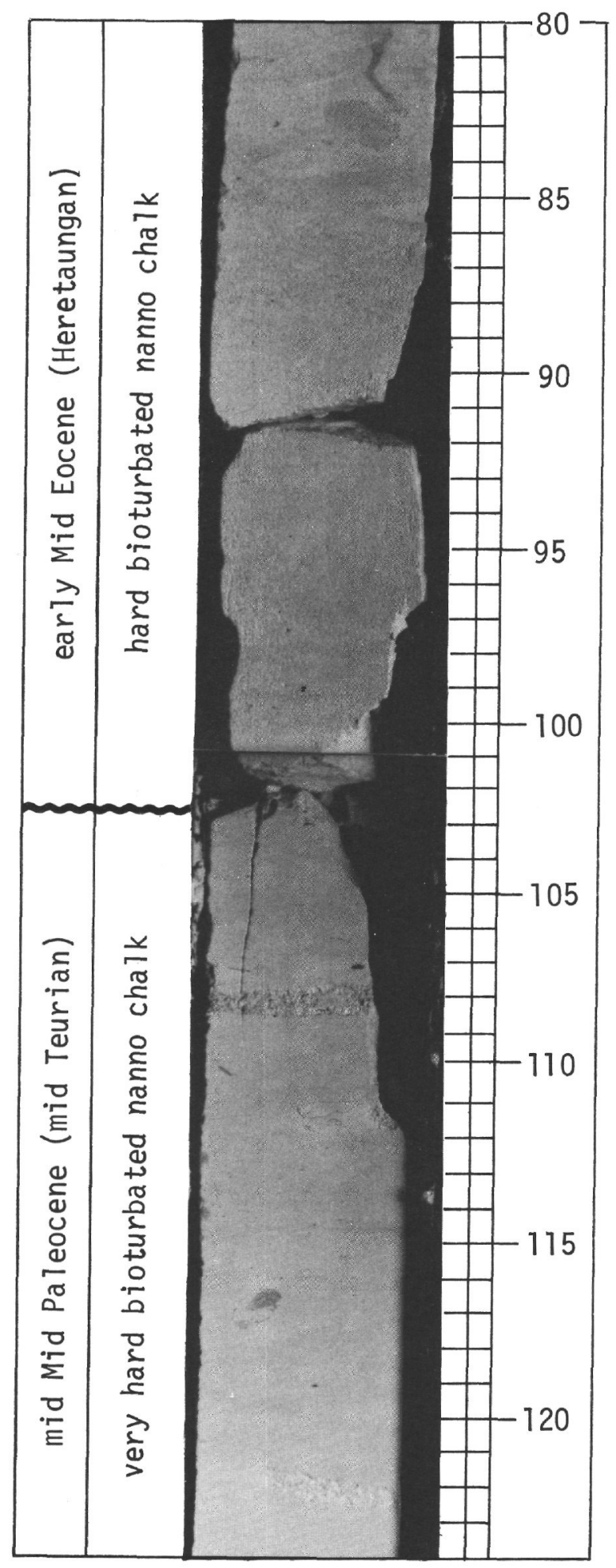

Figure 4. The Paleocene-Eocene unconformity at Site 208 (northern Lord Howe Rise) as recovered in 208-29-1. Approximately one-half natural size. 
Paleocene 2/3 (mid Teurian) Heliolithus kleinpelli Zones of both Edwards (1971) and Martini (NP6, 1971). All three samples contain much nannofossil debris plus minor reworking from Early Paleocene sediments. Thus, these nannofloras were almost certainly transported to this site by bottom currents prior to their deposition. The upper sample, from 208-29-1, $109-110 \mathrm{~cm}$, also contains minor contamination, which has probably come from the overlying sediments. However, in view of the very close proximity of this sample to the highest soft horizon (see above), it seems distinctly possible that this anomalous situation could have resulted from mid Eocene trace fossil activity rather than from contamination during drilling or laboratory operations. A foraminiferal sample at 208-29-2, 36 to $38 \mathrm{~cm}$ yielded a mid Paleocene assemblage which contains Maastrichtian reworking.

The unconformity is presumed to occur between two lengths of core at 208-29-2, $201 \mathrm{~cm}$. This position is adopted largely because the photographs of the archive half of the core show (Figure 4) fairly subtle but consistent changes in the texture, shade, mottling appearance, and degree of core breakage at this position. It seems most probably that the sediments overlying the unconformity are somewhat softer than those which underlie it. The shapes of the immediately adjacent lengths of core are suggestive of damage and loss of the contact during drilling operations. However, since an almost full core of consolidated sediment was taken, it is most unlikely that more than $5 \mathrm{~cm}$ of sediment is missing at this contact. This, plus the probable similar attitude of the underlying and overlying sediments (see above), suggests that the contact is either a disconformity or a paraconformity. No obvious lithologic or microfossil evidence for a significant depth change across this feature has been noted. The unconformity did not give a distinctive seismic reflection.

The overlying $63 \mathrm{~cm}$ of sediment was not differentiated from the underlying 2-meter bed in the visual core description. However, as indicated above, this consolidated nannofossil ooze interval appears to have slightly different lithologic characteristics. A sample from the top of this bed at 208-29-1, 45-47 cm, yielded Heretaungan (Mid Eocene) foraminifera. Just $8 \mathrm{~cm}$ higher, immediately above a thin chert horizon, a sample yielded an abundant and diverse, but poorly preserved, nannoflora which conforms to the mid Eocene 2/7 (mid Heretaungan) Discoaster elegans Zone of Edwards (1971). This flora, which also conforms to the Discoaster sublodoensis (NP14) Zone of Martini (1971), also contains mid Paleocene "reworking" (contamination?). Deposition, from a subtropical near-surface water mass, at depths well above the lysocline is indicated by the relative abundance of Zygrahablithus bijugatus and sparsity of nannoliths.

\section{Age}

In all three of the sequences described above, the unconformities invariably include all of the Late Paleocene $3 / 3$ to Early Eocene 2/5 (latest early Waipawan to latest mid Waipawan) interval (Table 2). It is distinctly possible (but see Site 207 above) that the unconformities also invariably include all of the immediately underlying interval, i.e., that all of the mid Paleocene $2 / 3$ to Early
Eocene 2/5 (latest Teurian to mid Waipawan) interval is involved. Put another way, the time span common to these unconformities covers, according to Berggren's (1969) time scale, about 2 million years.

That this feature is so closely centered on the Paleocene-Eocene boundary is very tantalizing. Are they both expressions of the same event or is their coincidence accidental?

\section{Possible Southwest Pacific Correlatives}

The unconformity was not recognized as such at Site 204, the only other Leg 21 sequence to reach this stratigraphic level. However, it could conceivably have once been present (see previous discussion under section "The Eocene-Oligocene Unconformity"). Of the other sequences drilled during Leg 21, only Sites 209 and 210 in the Coral Sea have some relevance in that holes at these sites bottomed in mid Eocene 6/7 and Early Eocene 5/5 sediments, respectively. Clearly, if this regional unconformity occurs in the unsampled parts of these sequences, the ages given above place some limit on its time span at these localities.

In New Zealand, the presence of small, but regional, unconformities at the Teurian-Waipawan and early Waipawan-mid Waipawan boundaries (i.e., within and at the top of the Late Paleocene) has long been suspected by the writer. In summary, this speculation is based on the following slender facts:

1) The first appearances of the planktonic foraminifera Globanomalina wilcoxensis and the calcareous nannofossil Marthasterites tribrachiatus, the events defining the base of the mid Waipawan (i.e., the Paleocene-Eocene boundary), are closely coincident in the two best studied sections (Edwards, 1971, p. 391). These two sequences are about 330 kilometers apart, and a common paraconformity is suspected but not proved. Its presence may explain why neither the short ranging $M$. contortus nor forms intermediate between this taxon and its successor $M$. tribrachiatus have been recorded from New Zealand (loc. cit.).

2) The early Waipawan (late Late Paleocene) is very thin compared to the underlying and overlying intervals (Edwards, 1971) but contains a disproportionately large number of planktonic microfossil events, especially at the base (Hornibrook and Edwards, 1971).

3) The Teurian-Waipawan boundary, which is within the Late Paleocene $2 / 3$ interval, can often be readily identified in the field by coincident abrupt changes in grain size, sediment type, and calcite content (Hornibrook in Fleming, 1959, pp. 396-399 and 444-445; Wilson, 1963; Brown et al., 1968, table 11.3; Kingma, 1971). This boundary, for many years considered to be the Mesozoic-Cenozoic boundary (Hornibrook, 1962), is also conspicuously marked by the last appearances of many arenaceous benthonic foraminifera (Hornibrook and Edwards, 1971, table 1). A regional unconformity, usually expressed as either a paraconformity or a disconformity, is suspected to occur at this boundary. Unfortunately, although the age of the base of the early Waipawan is known to be diachronous between several sequences (Edwards, 1971), the demonstration of similar age variations at the top of the Teurian is, at 
TABLE 2

The Biostratigraphic and Chronostratigraphic Extent of the Paleocene-Eocene

Regional Unconformity (Correlations Based on Edwards, 1971, figs. 2 to 5)

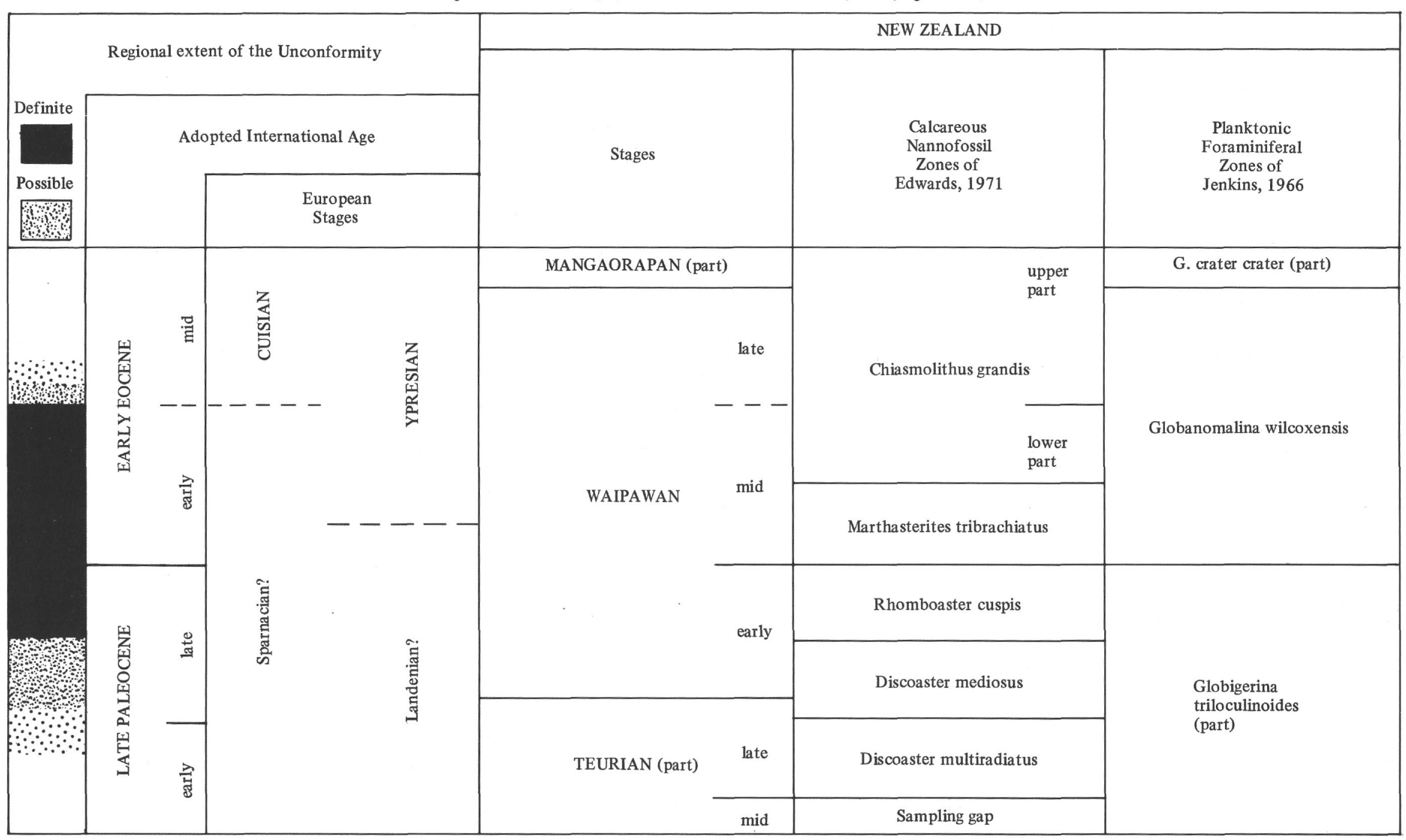


present, not possible due to the sparsity of planktonic calcareous microfossils in sediments of Teurian age. As far as the writer can determine, possible on-shore correlatives of this feature have not been recognized elsewhere in the southwest Pacific. This is not unsurprising in view of its known relatively short time span and the sparsity of published records of southwest Pacific early Paleogene marine sequences outside of the New Zealand region. However, it is worth mentioning the known occurrence of Late Paleocene planktonic foraminifera in the Otway Basin of Victoria, Australia (McGowran, 1970) and the apparent absence of Early Eocene sediments in eastern Papua (Davies \& Smith, 1971).

\section{THE MESOZOIC-CENOZOIC BOUNDARY}

\section{Occurrence}

This interesting boundary has been recognized in the Leg 21 Lord Howe Rise (Tasman Sea) Holes 207A and 208, which were spudded in at midbathyal (1400 to $1550 \mathrm{~m}$ ) depths, and some $10.85^{\circ}$ latitudinally apart (Figure 1). Descriptions of the situations observed at these locations are as follows.

\section{Site 207, Southern Lord Howe Rise}

It is unknown whether or not this boundary was recovered intact at this site, although it is known to occur between 207A-28-CC and 207A-29-2, $25 \mathrm{~cm}$, which were cored at a subbottom depth of 301 to 310 meters below a water column of 1393 meters. It could be at 207A-29-1, 30 $\mathrm{cm}$, but for the purposes of this report, a position between Cores 28 and 29 is adopted. The sediment underlying the boundary consists of a 48-meter-thick sequence of horizontally bedded olive black noncalcareous silty claystones (grade) which, although burrowed and mottled in places, are essentially homogeneous. Minor components include white medium sand grains, glauconite, pyrite, zeolite and, at the very top of Core 29, calcite. Apart from obvious downhole contamination, no nannofossils are present. Rare, poorly preserved arenaceous benthonic foraminifera, indicative of a Haumurian (latest Cretaceous) age, were recovered from the 207A-29-2, $25 \mathrm{~cm}$, to 207A-33-2, $117 \mathrm{~cm}$ interval. Additionally, one sample, 207A-31-2, 116-118 cm, yielded a small (calcareous) planktonic foraminiferal assemblage correlated with the late Haumurian (Maastrichtian) Globotruncana circumnodifer Zone of Webb $(1966,1972)$.

This boundary, which appears to have given a strong acoustic basement-seismic reflector, may well occur between the Core 28 corecatcher and the top of Core 29 . However, since no microfossils have as yet been obtained from the highest Core 29 section, a position as low as 207A-29-2, $25 \mathrm{~cm}$, is possible. Interestingly, a lithologic change from slightly calcareous olive gray (above) to noncalcareous olive black (below) sediments occurs at 207A-29-1, $30 \mathrm{~cm}$. If the Mesozoic-Cenozoic boundary is at this position, it seems likely that it is represented by either a paraconformity or a subtle disconformity. However, until more is known of the nature and age of this lithologic change, a positive identification as the boundary seems inadvisable. For this reason, a convenient position between
Cores 28 and 29 is adopted here. The near horizontal attitude of the underlying and overlying sediments argues against the presence of an angular unconformity at this site although such a feature may have occurred in the vicinity (see below).

The sediments immediately overlying the boundary are unfortunately very poorly represented in Core 28, which only achieved an $8 \%$ recovery. Most of the core recovered consists of olive gray, moderately mottled foraminifera- and pyrite-bearing nannofossil-rich calcareous claystone (grade). The few indications of bedding suggest a dip close to horizontal, an attitude consistent with those observed in the underlying and overlying intervals. The overlying very thin bed consists of medium gray nannofossil-bearing calcareous mudstone with a thin lamina of glauconite-rich sediment at the very top. Initially, the junction between these two lithologies was identified as the MesozoicCenozoic boundary. This was done because the lower lithology contains abundant and diverse, but poorly preserved, assemblages conforming to the Maastrichtian 3/3 (late Haumurian) part of the Nephrolithus frequens Zone of Edwards (1971), whereas, the upper lithology contains a small moderately well preserved nannoflora conforming to his Early Paleocene 4/5 (early Teurian) Prinsius martinii Zone. However, the lower assemblages are extremely fragmented and decrease in abundance upwards. Thus, a redeposited origin was soon suspected (see site report, Chapter 7). A foraminiferal sample taken at 207A-28-1, $137-139 \mathrm{~cm}$, confirms this supposition. It contains a varied assemblage of agglutinated and calcareous benthonic species of Teurian (Paleocene) age plus reworked Late Maastrichtian planktonic foraminifera and molluscan prisms. The source of this reworking is considered to be immediately to the north since this site was drilled on the south flank of a major acoustic basement high (see site report, Chapter 7).

The Mesozoic-Cenozoic boundary sequence at this site is not discussed further in this report. This is because of its rather special situation on the flanks of an old actively eroding volcano.

\section{Site 208, Northern Lord Howe Rise}

The boundary was recovered intact at this site (Figure 5) at 208-33-1, $57 \mathrm{~cm}$, which was cored at a subbottom depth of 576 meters below a water column of 1544 meters. Briefly, it consists of an apparent paraconformity which is closely underlain and overlain by disconformities. The lithostratigraphy of Cores 32 to 34 are described below in greater than normal detail because-

1) although condensed, this sequence is definitely far more complete than all of the Mesozoic-Cenozoic boundary sequences obtained on previous cruises of the Glomar Challenger;

2) the sediment type is markedly different from the chalks usually associated with this feature in the northern hemisphere;

3) relatively good biostratigraphic control can be provided (see Table 10, Chapter 18); and

4) the sequence recovered closely fits the lithofacies patterns suggested by the Tappan (1968) and Worsley (1971) Mesozoic-Cenozoic boundary models (see discussion in a later section of this chapter). 

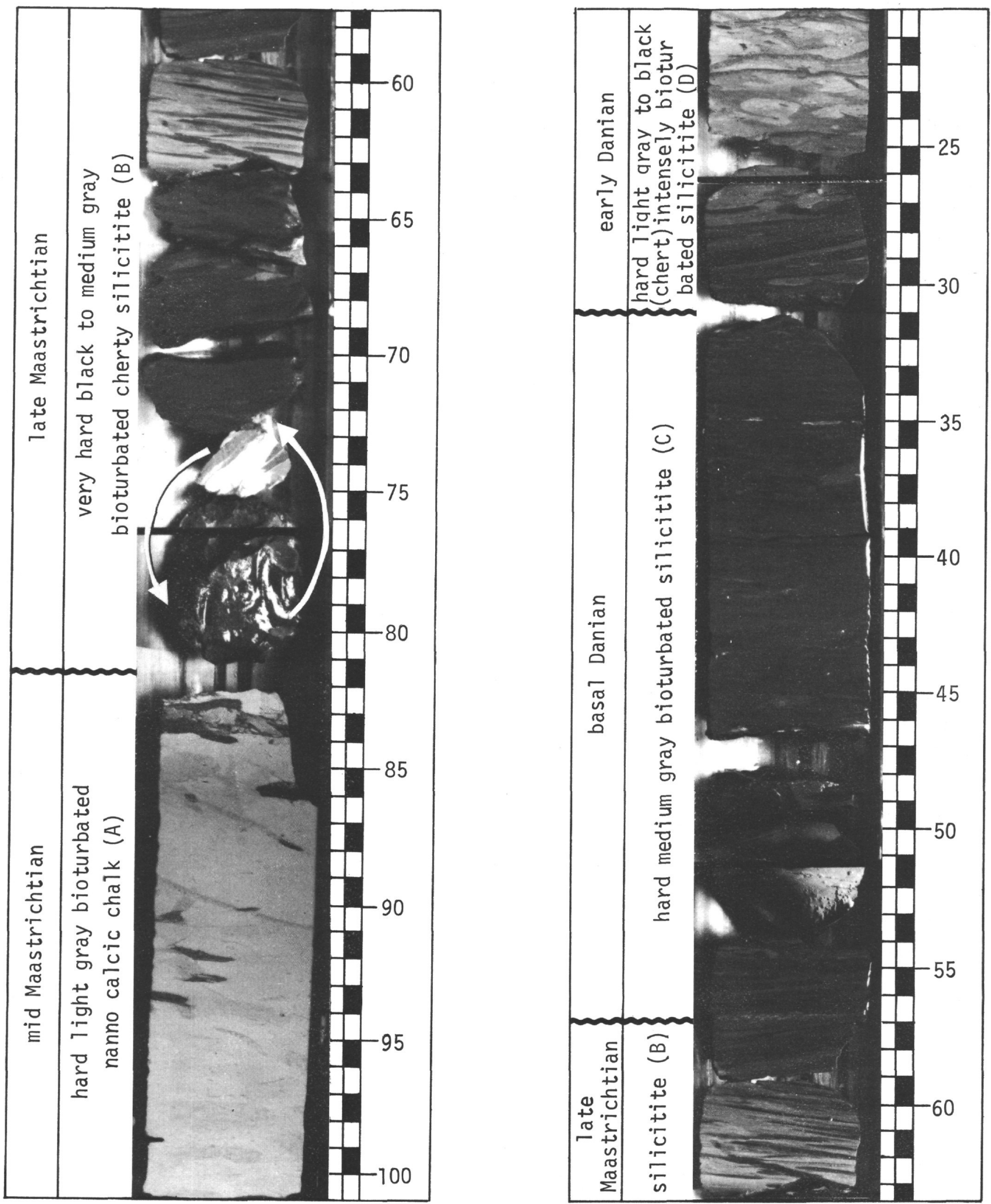

Figure 5. The Mesozoic-Ceñozoic (Maastrichtian-Danian) boundary at Site 208 (northern Lord Howe Rise) as recovered in 208-33-1. Approximately one-half natural size. 
The sequence is described in terms of four informal lithologic units which, for ease of reference, are labelled A to D in upward sequential order.

Unit A: This unit, which occurs between about 208-33-1, $80 \mathrm{~cm}, 1$ and 208-34-CC (the base of this hole), consists of at least 11 meters of hard light gray foraminifera-bearing bioturbated nannofossil calcic chalk containing several distinct layers of black or gray chert. Near the top of this unit, lenses of cherty material occupy one of the trace fossil burrows. Such selectivity suggests that this particular burrow is partly composed of younger (unit B) material which has been secondarily silicified. The large, partly silicified, cross-section photographed at 208-33-1, $83 \mathrm{~cm}$, centrally contains angular fragments of chalk, which have almost certainly been dislodged from the adjacent walls of the burrow. This situation clearly implies that the chalk was semi-consolidated at the time the burrow was made. Since lithification results from either burial or exposure of the sediment surface, the presence of an unconformity between units A and B seems distinctly likely. Unfortunately, the presence or absence of such a feature cannot be positively demonstrated because the contact between these two units was not recovered. However, the case for the presence of an unconformity is strongly supported, not only by the lithologic and, less clearly, paleontologic distinctiveness of unit A, but also by the rapid upward decrease in the nannofossil content of the highest part. Since the underlying and overlying intervals all show near horizontal relict bedding, the writer concludes that a disconformity occurs between units A and B. Unit A contains abundant poorly preserved ("mid") Maastrichtian 2/3 nannofossils (see Table 10, Chapter 18), well preserved and diverse "mid and late" Maastrichtian foraminifera having a high planktonic benthonic ratio, and rare poorly preserved "late" Maastrichtian Radiolaria. Siliceous sponge spicules are also present. The foraminifera suggest deposition at an oceanic midbathyal site, i.e., depositional conditions similar to those at present occurring at this location. However, the foraminifera nannofossil ratio observed in this unit is much lower than that in the Pleistocene sediments at this site thus suggesting that these Maastrichtian assemblages have been subjected to much more dissolution than those from the Pleistocene. This conclusion, plus the presence of thin-walled planktonic foraminifera presumed to be especially prone to dissolution (compare Berger, 1970, p. 130), suggests deposition not far above the lysocline. At present, the lysocline is at about 4250 meters in this area (Parker and Berger, 1971, fig. 15). Discussion of both this strong apparent contradiction with the depth suggested by the foraminifera and the probable deposition rates of units $A$ to $D$ is deferred until later in this account.

Unit B: This unit occurs between 208-33-1, $57 \mathrm{~cm}$, and about 208-33-1, $80 \mathrm{~cm}$ (but see previous footnote). It

\footnotetext{
${ }^{1}$ The exact position is uncertain due to the presence of a small chunk of unit A lithology between 72 and $75 \mathrm{~cm}$. For the purposes of this report this chunk of rock is considered to be an out of place fragment of uppermost unit A-a conclusion consistent with its shape, size, lithology, and nannofossil content.
}

consists of about $25 \mathrm{~cm}$ of very hard sediment which originally was probably composed of glass, nanno, siliceous sponge spicule, and radiolarian-bearing bioturbated very fine silty clay grade opal. However, this unit has been very substantially modified by secondary chert. Consequently, the sediment now grades up from a basal black lustrous chert through very dark gray laminated chert to a medium gray (silty clay grade) silicitite with numerous dark gray cherty laminations. As judged by relict horizontal bedding observed at $57 \mathrm{~cm}$ and $62 \mathrm{~cm}$, most of these lamina are at about $5^{\circ}\left(0^{\circ}\right.$ to $8^{\circ}$ range $)$ to the bedding, but others clearly coincide with relicts of trace fossil burrows. Evidence that the base of this unit unconformably overlies the underlying chalk has already been given above; the nature of the top of unit B is discussed under unit C. From the basal black chert, abundant siliceous sponge spicules and pyritized "late" Maastrichtian Radiolaria have been recorded. The uppermost, and least altered, part of this unit provided small assemblages of ("late") Maastrichtian 3/3 nannofossils. These nannofossil samples consist almost entirely of subangular to rounded very fine silt and (especially) clay-sized particles of opal suspected to be of siliceous microfossil origin. Devitrified acid glass is almost certainly present in 208-33-1, $58 \mathrm{~cm}$, but no grains with the characteristic shape of vitroclastic shards were observed. Clearly the depositional environment, although still oceanic, was very different from that of the underlying unit. A position well below the lysocline and very close to the nannofossil compensation depth seems distinctly probable (see discussion below).

Unit C: This unit occurs between 208-33-1, $31 \mathrm{~cm}$, and $208-33-1,57 \mathrm{~cm}$. It consists of $26 \mathrm{~cm}$ of hard medium gray nannofossil (and probably siliceous microfossil) bearing bioturbated (very fine silty clay grade) silicitite which, especially near the base, has been modified by secondary chert. The base of this unit consists of a $2-\mathrm{mm}$ interval of rounded white granules which might be reworked chalk. In detail, this interval consists of two closely spaced horizontal bands of granules which are crossed by a third slightly sigmoid band. It seems probably that slight scour occurred during the deposition of the interval. Since this feature very closely corresponds to the paleontologically most prominent Mesozoic-Cenozoic boundary (see Table 10, Chapter 18 ), its base is considered here to be a paraconformity. However, it should be emphasized that apart from these bands of granules, no observable lithologic change occurs across this boundary (Figure 5). But characters which were originally distinctive could well have become unrecognizable during the secondary chertification evident in this basal interval. A 1-cm-thick segment of black lustrous chert occurs at $49 \mathrm{~cm}$. It is overlain by much less altered silicitite which, despite strong bioturbation, contains slightly undulating horizontal bedding planes at $40 \mathrm{~cm}, 38 \mathrm{~cm}$, and $35 \mathrm{~cm}$. A nannofossil sample at $45 \mathrm{~cm}$ mainly consists of very finely divided opal (refractive index about 1.46), but it also contains a few small grains of quartz, minor fine grained clacite, and rare glauconite. Unit $\mathrm{C}$ contains very small nannofloras of Early Paleocene 1/5 (basal Danian) age at $54 \mathrm{~cm}$ and $36 \mathrm{~cm}$ (Table 10, Chapter 18). The conditions and rate of deposition were clearly very similar to those of unit B (q.v.). 
Unit D: This unit, which is at least $13 \mathrm{~cm}$ thick, has its base at 208-33-1, $31 \mathrm{~cm}$, but the position of its top is unknown due to the minimal recovery of the overlying Core 32. This unit consists of hard light gray through to black nannofossil (and probably siliceous microfossil) bearing very fine silty clay grade silicitite. It has been subjected to extensive burrowing (mostly greenish gray) and, especially basally, subsequent chertification (moderate: medium to dark gray; intense: black). This silicitite is underlain by a thin horizontal layer of black lustrous chert which is adopted here as the base of unit D. The reasons for this position being accepted are as follows. Firstly, it closely corresponds to a rapid upward increase in the degree of bioturbation. Secondly, in the underlying units $\mathrm{C}$ and $\mathrm{B}$, a distinct tendency for sedimentary breaks to be chertified was noted (e.g., the bedding planes at $38 \mathrm{~cm}, 40 \mathrm{~cm}$, and 62 $\mathrm{cm}$ plus the basal unit $\mathrm{B}$ disconformity). Thirdly, this position is close to a biostratigraphic boundary (see Table 10, Chapter 18). Lastly, the light colored mottling at the top of the underlying unit $\mathrm{C}$ could represent burrows resulting from unit D trace fossil activity. Indeed, the similarity of the situation at this position with that at the base of unit B is suggestive of the presence of a disconformity at $208-33-1,31 \mathrm{~cm}$. Unit D contains very small nannofloras of Early Paleocene 2/5 (early Danian) age at $30 \mathrm{~cm}, 23 \mathrm{~cm}$, and $20 \mathrm{~cm}$. A foraminiferal sample taken at 21 to $23 \mathrm{~cm}$ yielded sparse broken calcareous benthonic foraminifera plus abundant fish teeth and siliceous sponge spicules. The conditions and rate of deposition of this unit were obviously very similar to those of the underlying units $\mathrm{B}$ and $\mathrm{C}$. The absence of planktonic foraminifera confirms, as is much more spectacularly demonstrated in the Oligocene of Site 205, that it is incorrect to assume the planktonic foraminiferal and nannofossil compensation depths are identical. The top of this unit probably gave the strong seismic reflection observed at about this level.

The corecatcher is the only part of core 32 recovered. It differs from the sediments of units $B$ to $D$ in two conspicuous ways. Firstly, it contains much higher numbers of both nannofossils and, especially, siliceous microfossils. Secondly, the fine-grained opal present is noticeably smaller in amount, larger in grain size (mostly very fine silt), and more irregular in shape. There can be no doubt that this opal has resulted from the comminution, presumably largely by dissolution, of diatoms and Radiolaria. This situation clearly implies that not only is the silty clay grade opal of units $\mathrm{B}$ to $\mathrm{D}$ of biogenic origin but also that the nannofossil compensation depth had retreated somewhat from its formerly higher position. The depositional conditions were obviously less harsh than those of the underlying units B to D. The nannofossils present in 32-CC indicate an Early Paleocene $3 / 5$ (Danian) age. Because of the corecatcher sample's small size, it was not examined for foraminifera. However, since 32-CC is intermediate in nannofossil content between the overlying and underlying lithofacies, which are with and without planktonic foraminifera respectively, it seems likely that calcareous benthonic and perhaps planktonic foraminifera are present.

\section{Site 208 Paleogeography}

Before discussing the significance of the sequence obtained across the Mesozoic-Cenozoic boundary at Site 208 , it seems desirable to quantify as accurately as possible the paleogeographic position and general depositional conditions of the sequence at that time.

Application of the polar wandering path given for Australia by Wellman et al. (1969) to Site 208 would imply a position about $22^{\circ}$ further south at this time. Although subsequent sea floor spreading may have occurred in the adjacent Tasman Basin, the shape and narrowness of this basin's northern part suggests that the latitude of Site 208 would not be greatly changed. Accordingly, a position at about $50^{\circ} \mathrm{S}$ at the Mesozoic-Cenozoic boundary seems reasonable.

According to Berger (1972, p. 394), the isostatic response to subsequent sediment loading approximates to one-half of the overlying sediment thickness. Application of this rough correction suggests that the Site 208 Mesozoic-Cenozoic boundary was at about 1800 meters below sea level (i.e., midbathyal). Apart from the Early Paleocene, this depth is consistent with the foraminiferal assessments of bathymetric position. It is also consistent with those deduced from Eocene and younger nannofloras. The writer therefore concludes that the absence of earliest Paleocene planktonic foraminifera is due to exceptional environmental conditions (see below) rather than to a shortlived pattern of ridge uplift and downdrop.

Definite deposition rates unfortunately cannot be determined for the Maastrichtian-Danian interval at Site 208. This is because of the presence of several unconformities and the absence, in all of the intervening intervals, of the two or more distinct biostratigraphic events necessary to provide reference points. One could ignore the presence of the unconformities but, unless the estimated time (Berggren, 1969) or compaction (Hamilton, 1959, table 1) values are incorrect, the resultant deposition rates provide one of the most convincing arguments for their existence. For example, utilizing the time scale of Berggren (1969) provides a reasonable rate (including compaction) of greater than 7 meters per million years for Unit A but the most unlikely rate of about 0.25 meters per million years for units B and C. However, on lithologic grounds there can be no doubt that unit A (chalk) was deposited at an appreciably faster rate than the overlying units B to D (silicitite). Furthermore, rough estimates should be obtainable by analogy with modern deposition rates at similar positions relative to the lysocline and calcium carbonate compensation depth. Unfortunately, the necessary information to use this method using only southwest Pacific data is not yet available. However, extrapolation of the southwest Pacific plank tonic foraminiferal lysocline (L) and compensation depth (CD) data given by Parker and Berger (1971, fig. 14e) to the modern south Atlantic deposition rates given by Berger (1972, fig. 4) via the 500 meter upward adjustment indicated by Berger (1970, fig. 8) suggests the following deposition rates in meters per million years: 


\begin{tabular}{llll}
\hline \multicolumn{1}{c}{ Interval } & \multicolumn{1}{c}{ Lithofacies } & Positiona $^{\mathrm{a}}$ & Deposition Rate \\
\hline Cores 30 to 32 & nannofossil silicitite & $<\mathrm{L}$ & $\sim 5$ \\
Units B to D & "clay" silicitite & $<\mathrm{CD}$ & $\sim 2.5$ \\
Unit A & $\begin{array}{l}\text { nannofossil calcitic } \\
\text { chalk }\end{array}$ & $>\mathrm{L}$ & $\sim 10$ \\
& \multicolumn{2}{c}{} & \\
\hline
\end{tabular}

aSensu planktonic foraminifera not nannofossils.

bExcluding compaction. According to Hamilton (1959) under a 600 meter sediment load units B to D would compact to a little under one-half their former size but the other intervals would compact to a much lesser degree.

The shipboard sedimentologists and paleontologists all agree that this site was fully oceanic throughout the sequence drilled. Furthermore, as might be expected from this site's former mid latitude position (see above), the microfossil assemblages obtained across the Mesozoic-Cenozoic boundary include, as well as many cosmopolitan species, Austral (i.e., extra-Tethyan) realm elements such as the nannofossils Nephrolithus and Hornibrookina. Tethyan late Cretaceous taxa such as Ceratolithoides, Marthasterites (sensu stricto), and Tetralithus are not present, and double-keeled Globotruncana are pauperate.

\section{Discussion}

As was mentioned above, the lithofacies pattern encountered across the Mosozoic-Cenozoic boundary at Site 208 closely corresponds to those suggested by Tappan's (1968) and Worsley's (1971) models for this boundary. Briefly, both models suggest that phytoplankton productivity produced, via very different mechanisms, a marked change in the amount of atmospheric carbon dioxide and thus an even more conspicuous increase in the amount of calcium carbonate dissolution. At the Mesozoic-Cenozoic boundary, the dissolution became so extreme as to cause both a world-wide marine unconformity (usually expressed as a paraconformity) and the abrupt extinction of numerous nektonic and planktonic taxa, especially those having calcareous skeletons. The best means of documenting the degree of dissolution is by determining the changes with time of the bathymetric positions of the lysocline and underlying calcium carbonate compensation depth (CCD). Both Tappan (1968, caption to fig. 1) and Worsley (1971) suggested that the CCD rapidly rose to near the ocean surface just prior to the boundary but took significantly longer to return to its more normal position of 4000 to 5000 meters. Thus, the time missing at the Mesozoic-Cenozoic boundary should show a distinct tendency to increase asymmetrically with increasing bathymetric depth since the areas below the CCD at any given time, having a much slower deposition rate than those well above the CCD, would be much more prone to erosion.

However, within the limits imposed by present biostratigraphic resolution, such a tendency is not conspicuous judging by the data available in the literature. For example, the midbathyal Site 208 sequence (see above) appears to be no less complete across the boundary than the shelf sequence at Miller's Ferry in Alabama (Hay and Mohler, 1967, pp. 1516; Cepek and Hay, 1969, fig. 4) or the (?shelf) basin sequence at Paderno d'Adda in northern Italy (Cita et al., 1968). On the other hand, Site 208 is more complete across the boundary than both the shelf sequences at Maastricht in Holland and, less certainly, at Stevn's Klint in Denmark (see Chapter 18) and the probably former lower bathyal sequences at DSDP Sites 20 and 21 in the South Atlantic (Worsley, 1971). The three most complete boundary sequences mentioned above appear to have been deposited under markedly different geographic and bathymetric conditions. Thus, it seems highly probably that the amount of time missing at the boundary in a given sequence is related to rate of deposition and degree of exposure to erosive agencies such as bottom and tidal currents. If this is correct, the boundary event itself is isochronous and the most complete sequences will generally be found to occur in small local basins, especially those with a definite sill, on paralic and epicontinental shelfs. But near complete sequences will occur in similar situations on borderland, plateau, and isolated broad rise platforms.

If, as seems highly probable, the Mesozoic-Cenozoic boundary event is isochronous, what could have caused it and the associated major floral and faunal turnover? Tappan (1968) suggested that either the oxygen minimum zone or the CCD reached the surface of the world's oceans and thus caused both world-wide marine dissolution of limestone and simultaneous massive extinctions amongst calcareous taxa. Later, and more explicitly, Hay (in Benson et al., 1970, p. 672) suggested that it was the CCD that reached the surface, but Worsley (1971) viewed this idea with some scepticism. The writer, despite a careful visual and photographic examination of the intact Site 208 boundary, observed no indication of greater dissolution than at the immediately adjacent positions known to contain nannofossils and thus undoubtedly above the CCD. However, since slight scour has occurred at this boundary at Site 208 (see descriptive section above), the record of the CCD's final ascent and descent could have been lost. Clearly, it would be most desirable to obtain detailed petrographic observations across the Site 208 paraconformity.

It seems more likely that it was the lysocline and not the CCD that caused the observed dissolution of shelf sediments during the boundary event. Regardless of whether this supposition is correct or not, the entry of either into the large expanses of epicontinental sea known to occur at this time would have substantially modified the chemistry of the photic zone, mainly by greatly increasing the amount of dissolved calcium. Initially, this situation may have favored coccolithophorid production, but as it rapidly intensified, these organisms would soon have found it intolerable. Faced with either extinction or much reduced production, it seems likely that they would have adapted by ceasing to produce coccolith calcite. If these hostile conditions persisted for more than a few thousand years, many species would have lost this ability 
permanently. Those taxa accustomed to, or able to, tolerate highly variable or very harsh environments should have had their ability to calcify least affected and most should cross the boundary without any apparent break in their fossil record.

That this line of reasoning is probably correct is suggested by the following supporting evidence. Firstly, experimental studies by Isenberg and his coworkers (1964 and 1965) on the brackish-water coccolithophorid Hymenomonas carterae indicate that the production of coccolith calcite is a physiological attribute of mature cells and is independent of photosynthesis. Despite this, it has an absolute requirement for calcium, its response to external values being as follows:

$$
\mathrm{Ca}^{+2}
$$

\begin{tabular}{ll}
\hline Above $10^{-2} \mathrm{M}$ & No growth but the cells remain viable. \\
$10^{-2}$ to $10^{-3} \mathrm{M}$ & Optimum growth and coccolith mineralization. \\
Below $10^{-5} \mathrm{M}$ & No coccolith mineralization \\
Below $10^{-6} \mathrm{M}$ & No growth but the cells remain viable.
\end{tabular}

However, this species has only a motile stage and thus cannot encyst. This suggests that if faced with hostile conditions for a long time, it might not survive. But the closely related fresh water species Hymenomonas roseola, which also appears to have only a motile stage, has remained viable in laboratory cultures for some 20 years despite an increasing tendency not to produce coccolith calcite (Manton and Peterfi, 1969, p. 3 and 11). This suggests that the actual response of this genus to prolonged hostile conditions is loss of its ability to mineralize its coccolith scales. Secondly, there is the interesting on/off coccolith calcifying response to low versus normal available nitrogen shown (in laboratory studies by Wilbur and Watabe, 1963) by a mutant of Emiliania huxleyi, the dominant living marine coccolithophorid. However, this mutant deposits internal calcium carbonate when it does not deposit this mineral on its coccolith scales. Thirdly, as Black (1968, pp. 809-811) has pointed out, certain living species of the coccolithophorid-like genus Crysochromulina produce unmineralized scales strongly reminiscent in their architecture to Deflandrius and Eiffellithus. The latter are two characteristically late Cretaceous forms which make their highest fossil record appearances immediately below the Mesozoic-Cenozoic boundary. Fourthly, there is the well known abrupt crystalographic change, without substantial structural modification, in the WatznaueriaCoccolithus group across this boundary (Black, 1968, p. 797 and P1. 143; Perch-Nielson, 1969, p. 322). This situation seems to provide clear evidence that at least one group of coccolithophorids had its ability to mineralize its coccolith scales affected during the boundary event. Lastly, the encysting genera Braarudosphaera and Thoracosphaera are amongst the very few nannofossils to survive this event unchanged and are sometimes prominent in earliest Danian nannofloras (Bramlette and Martini, 1964, pp. 305-306). These forms are characteristic of near-shore and deep-sea environments, respectively (Bernard, 1942, Table 6-as Syracosphaera heimii; Bukry et al., 1971, p. 1262 and table 1; Takayama, 1972).
The above information strongly implies, in the writer's opinion, that the spectacular nannofloral change at the Mesozoic-Cenozoic boundary does not result from simultaneous massive extinctions. Rather, it largely results from the environmentally induced last fossil records of taxa subsequently incapable of fossilization. If this is correct, both a mechanism by which to adequately explain the paleontology of the Mesozoic-Cenozoic boundary, and a laboratory tool with which to quantify aspects of the near-surface water chemistry at this time, are provided. The other groups of plankton and nekton that have their last appearances below the boundary event are presumably those that depended, directly or indirectly, on the deposition of calcium carbonate skeletons and could not survive without this mineral. The calcareous benthonic organisms which survive the boundary event are presumably those which, like the nannofossils Braarudosphaera and Thoracosphaera, were able to tolerate very harsh or highly variable environments. It is hard to envisage this method of survival being applicable to groups with internal skeletons.

Finally, the writer would like to draw attention to an interesting situation. When the calcite content of the sequence across the boundary at Site 208 is compared with equivalent New Zealand sequences (Edwards, 1971; Webb, 1971), it is found that the calcite correlation is strongly negative in the latest Mesozoic but more or less positive in the earliest Cenozoic. This situation strongly implies geographic, perhaps roughly latitudinal, variability in the level of the CCD or lysocline at this time. Parker and Berger (1971, fig. 15) have demonstrated that such a variability occurs in the present day South Pacific lysocline.

\section{REFERENCES}

Andrews, P. B., 1963. Stratigraphic Nomenclature of the Omihi and Waikari Formations, North Canterbury: New Zealand Geol. Geophys. J., v. 6(2), p. 228-256.

Barrett, P. J., 1967. Te Kuiti Group in the Waitomo-Te Anga Area: New Zealand Geol. Geophys. J., v. 10(4), p. 1009-1026.

Benson, W. N., 1969. Dunedin District 1:50,000: New Zealand Geol. Surv. Misc. Ser., Map 1, Wellington (Dept. Sci. Industr. Res.), 18 p.

Benson, W. E., Gerard, R. D., and Hay, W. W., 1970. Summary and Conclusions: Initial Reports of the Deep Sea Drilling Project, Volume IV. Washington (U. S. Government Printing Office), p. 659-673.

Berger, W. H., 1970. Planktonic Foraminifera: Selective Solution and the Lysocline: Marine Geol., v. 8, p. 111-138.

, 1972. Deep Sea Carbonates: Dissolution Facies and Age-Depth Constancy: Nature, v. 236(5347), p. 392-395.

Berggren, W. A., 1969. Cenozoic Chronostratigraphy, Planktonic Foraminiferal Zonation and the Radiometric Time Scale: Nature, v. 224, p. 1072-5.

Bernard, F., 1942. Essai sur les Facteurs de Repartition des Flagelles Calcaires: Ann. Inst. Oceanogr., v. 21, p. 29-112.

Black, M., 1968. Taxonomic Problems in the study of coccoliths: Paleontology, v. 11(5), p. 793-813.

Bramlette, M. N. and Martini, E., 1964. The great change in calcareous nannoplankton fossils between the Maestrich- 
tina and Danian: Micropaleontology, v. 10(3), p. 291-322.

Brown, D. A., Campbell, K. S. W., and Crook, K. A. W., 1968. The Geological Evolution of Australia and New Zealand: Oxford (Pergamon Press).

Bukry, D., Douglas, R. G., Kling, S. A., and Krasheninnikov, V., 1971. Planktonic Microfossil Biostratigraphy of the North western Pacific Ocean: Initial Reports of the Deep Sea Drilling Project, Volume VI. Washington (U.S. Government Printing Office), p. 1253-1300.

Burns, R. E., Andrews, J. E., van der Lingen, G. J., Churkin, M., Galehouse, J. S., Packham, G. H., Davies, T. A., Kennett, J. P., Dumitrica, P., Edwards, A. R., and Von Herzen, R.P., 1972. Glomar Challenger Down Under, Deep Sea Drilling Project Leg 21: Geotimes, v. 17(5), p. 14-16.

Carter, R. M. and Landis, C. A., 1972. Correlative Oligocene Unconformities in Southern Australasia: Nature Phys. Sci., v. 237(70), p. 12-13.

Cepek, P. and Hay, W. W., 1969. Calcareous Nannoplankton and Biostratigraphic Subdivision of the Upper Cretaceous: Gulf Coast Assoc. Geol. Soc. Trans., v. 19, p. 323-336.

Cita, M. B., Premoli-Silva, M., Toumarkine, M., Bolli, H. M., Luterbacher, H. P., Mohler, H. P., and Schaub, H., 1968. Le Paleocene et l'Eocene de Paderno d'Adda: Colloque Eocene, Paris, 1968, B.R.G.M., Mem. 58, p. 611-627.

Davies, H. L. and Smith, I. E., 1971. Geology of Eastern Papua: Geol. Soc. Am. Bull., v. 82(12), p. 3299-3312.

Edwards, A. R., 1971. A Calcareous Nannoplankton Zonation of the New Zealand Paleogene: Plank. Conf., 2nd, Roma 1970, p. 381-419.

Fleming, C. A. (Ed.), 1959. New Zealand. In Lexique Stratigraphique International, Oceania: Paris (Centre National Recherche Sci. for Internatl. Geol. Congr.), pt. 4, $527 \mathrm{p}$.

Gage, M., 1957. The Geology of Waitaki Subdivision: New Zealand Geol. Surv. Bull. n.s., v. 55.

Gair, H. S., 1959. The Tertiary Geology of the Pareora District, South Canterbury: New Zealand Geol. Geophys. J., v. 2(2), p. 265-296.

1962. Notes on the Geology of the Blue Mountain District, South Canterbury: New Zealand Geol. Geophys. J., v. 5(1), p. 178-188.

Hamilton, E. L., 1959. Thickness and Consolidation of Deep-Sea Sediments: Geol. Soc. Am. Bull., v. 70(11), p. 1399-1424.

Hay, W. W. and Mohler, H. P., 1967. Calcareous Nannoplankton from Early Tertiary Rocks at Pont Labau, France and Paleocene-Early Eocene Correlations: J. Paleont., v. 41(6), p. 196-206.

Hornibrook, N.de B., 1962.

, 1967a. The Stratigraphy of Landon (or Boundary)

Creek, Oamaru: New Zealand Geol. Geophys. J., v. 9(4), p. 458-70.

, 1967b. Eocene and Oligocene Sedimentary Cycles in New Zealand (A comment): New Zealand Geol. Geophys. J., v. 10(4), p. 1159-61.

Hornibrook, N.de B. and Edwards, A. R., 1971. Integrated Planktonic Foraminiferal and Calcareous Nannoplankton Datum Levels in the New Zealand Cenozoic: Plank. Conf., 2nd, Roma 1970, Proc., p. 649-657.

Hutton, F. W., 1877. Report on the Geology of the North-east Portion of the South Island, from Cook Straits to the Rakaia: New Zealand Surv. Rep. Geol. Explor. 8(1873-4), p. 27-58.
Isenberg, H. D. and Lavine, L. S., 1964. Comparative biology of mineral deposition. In Current Practice in Orthopaedic Surgery: St. Louis, v. 2, p. 177-219.

Isenberg, H. D., Lavine, L. R., Weissfellner, H., and Spotnite, A., 1965. The Influence of Age and Heterotrophic Nutrition on Calcium Deposition in a Marine Coccolithophorid Protozoan: New York Acad. Sci. Trans., Ser. II, v. 27(5), p. 530-545.

Johnson, D. A., Hollister, C. D., and Lonsdale, P. F., 1972. Carbonate Sedimentation and Abyssal Circulation in the Samoan Passage: Geol. Soc. Am. Abstr. Progr., v. 4(7), p. 554 .

Kennett, J. P., Burns, R. E., Andrews, J. E., Churkin, M., Davies, T. A., Dumitrica, P., Edwards, A. R., Galehouse, J. S., Packham, G. H., and van der Lingen, G. J., 1972. Australian-Antarctic Continental Drift, Paleocirculation changes and Oligocene Deep-Sea Erosion: Nature Phys. Sci., v. 239, p. 51-55.

Kingma, J. T., 1971. Geology of Te Aute Subdivision: New Zealand Geol. Surv. Bull. n.s., v. 70.

Lillie, A. R. and Brothers, R. N., 1970. The Geology of New Caledonia: New Zealand Geol. Geophys. J., v. 13(1), p. 145-183.

Ludbrook, N. H., 1967. Correlation of Tertiary Rocks of the Australasian Region. In Tertiary Correlations and Climatic Changes in the Pacific: Pacific Sci. Congr., 11 th, Tokyo 1966, Symposium 25, p. 7-19.

Ludbrook, N. H. and Linsay, J. M., 1967. Tertiary Foraminiferal Zones in South Australia: Internat. Conf. Plank. Microfossils, 1 st, Proc., v. 2, p. 366-374.

MacPherson, E. O., 1946. An outline of Late Cretaceous and Tertiary Diastrophism in New Zealand: New Zealand Dep. Sci. Ind. Res. Geol. Mem. 6.

Manton, I. and Peterfi, L. S., 1969. Observations on the fine structure of coccoliths, scales and the protoplast of a freshwater coccolithophorid, Hymenomonas roseola Stein, with supplementary observations on the protoplast of Cricosphaera carterae: Roy. Soc. London Proc. Sen B, v. 172, p. 1-15.

Martini, E., 1971. Standard Tertiary and Quaternary Calcareous Nannoplankton Zonation: Plank. Conf., 2nd, Roma, 1970, Proc., p. 739-785.

Mason, B., 1948. Tertiary Rock Strata at Coal Creek, Rangitata River: New Zealand Sci. Techn. J., v. 29(3) (sec. B), p. 121-126.

McGowran, B., 1970. Late Paleocene in the Otway Basin: Biostratigraphy and the Age of Key Microfaunas. Roy. Soc. South Australia Trans., v. 94, p. 1-14.

McTavish, R. A., 1966. Planktonic Foraminifera from the Malaita Group, British Solomon Islands: Micropaleontology, v. 12(1), p. 1-36.

Palmieri, V., 1971. Tertiary Subsurface Biostratigraphy of the Capricorn Basin: Geol. Surv. Queensland Rep. 52, p. $1-18$.

Parker, F. L. and Berger, W. H., 1971. Faunal and solution patterns of planktonic Foraminifera in surface sediments of the South Pacific: Deep-Sea Res., v. 18(1), p. 73-107.

Perch-Nielsen, K., 1969. Elekronmikroskopische Untersuchungen der Coccolithophoriden der Dan-Scholle von Katharinenhof (Fehmarn): N.Jb. Geol. Paleont. Abh., v. 132(3), p. 317-332.

Ridd, M. F., 1964. Succession and Structural Interpretation of the Whangara-Waimata Area, Gisborne, New Zealand: New Zealand Geol. Geophys. J., v. 7(2), p. 279-298.

Rodda, P., 1967. Outline of the Geology of Viti Levu: New Zealand Geol. Geophys. J., v. 10(5), p. 1260-1273. 
Sclater, J. C., Anderson, R. N., and Bell, M. L., 1971. Elevation of Ridges and Evolution of the Central Eastern Pacific: J. Geophys. Res., v. 76(32), p. 7888-7915.

Takayama, T., 1972. A note on the distribution of Braarudosphaera bigelowi (Gran \& Braarud) Deflandre in the bottom sediments of Sendai Bay, Japan: Paleont. Soc. Japan, Trans. Proc. n.s., v. 87, p. 429-435.

Tappan, H., 1968. Primary Production, Isotopes, Extinctions and the Atmosphere: Paleogeogr., Paleoclim., Paleoecol., v. 4, p. 187-210.

Thompson, J. A., 1920. The Notocene Geology of the Middle Waipara and Weka Pass District, North Canterbury, New Zealand: New Zealand Inst. Trans., v. 52, p. $322-415$.

Thomson, J. A., 1926. Marine Phosphatic Horizons in the Tertiary Limestones and Greensands of South Canterbury and North Otago, and Brachiopod Evidence as to their Age: New Zealand Sci. Tech. J., v. 8(3), p. 143-160.

Vella, P., 1967a. Eocene and Oligocene Sedimentary Cycles in New Zealand: New Zealand Geol. Geophys. J., v. 10(1), p. 119-145.
Vella, P., 1967b. Eocene and Oligocene Sedimentary Cycles in New Zealand (A Reply): New Zealand Geol. Geophys. J., v. 10(4), p. 1162-4.

Webb, P. N., 1966. New Zealand Late Cretaceous Foraminifera and Stratigraphy: Utrecht (Schotanus and Jens-Utrecht, N. V.), 20 p. , 1971. New Zealand Late Cretaceous (Haumurian) Micropaleontology and Biostratigraphy (A Summary): New Zealand Geol. Geophys. J., v. 14(4), p. 795-828.

Wellman, H. W., 1953. The Geology of Geraldine Subdivision: New Zealand Geol. Surv. Bull. n.s., v. 50.

Wellman, P., McElhinny, M. W., and McDougall, I., 1969. On the Polar-Wander Path for Australia during the Cenozoic: Roy. Astro. Soc. Geophys., v. 18, p. 371-395.

Wilbur, K. M. and Watabe, N., 1963. Experimental studies on calcification in molluscs and the alga Coccolithus huxleyi: New York Acad. Sc. Ann., v. 109, p. 82-112.

Wilson, D. D., 1963. Geology of Waipara Subdivision (Amberley and Motunau Sheets S68 and S69): New Zealand Geol. Surv. Bull. n.s., v. 64, p. 1-122.

Worsley, T. R., 1971. The Terminal Cretaceous Event: Nature, v. 230 (5292), p. 318-320. 